Illinois State University

ISU ReD: Research and eData

Theses and Dissertations

8-22-2019

\title{
You Belong Here: Residence Halls as Disparate Predictors of Sophomore Year Persistence at Predominantly White Institutions
}

James Raymond Neville

Illinois State University, nevillejamie@gmail.com

Follow this and additional works at: https://ir.library.illinoisstate.edu/etd

Part of the Higher Education Administration Commons, and the Higher Education and Teaching Commons

\section{Recommended Citation}

Neville, James Raymond, "You Belong Here: Residence Halls as Disparate Predictors of Sophomore Year Persistence at Predominantly White Institutions" (2019). Theses and Dissertations. 1170.

https://ir.library.illinoisstate.edu/etd/1170

This Dissertation is brought to you for free and open access by ISU ReD: Research and eData. It has been accepted for inclusion in Theses and Dissertations by an authorized administrator of ISU ReD: Research and eData. For more information, please contact ISUReD@ilstu.edu. 


\section{YOU BELONG HERE: RESIDENCE HALLS AS DISPARATE PREDICTORS OF SOPHOMORE YEAR PERSISTENCE AT PREDOMINANTLY WHITE INSTITUTIONS}

\section{JAMES RAYMOND NEVILLE}

107 Pages

The goal of this study is to compare the influence of residence hall living on student persistence between White and nonwhite students at predominantly White institutions. The Beginning Postsecondary Students (BPS) 2012/2014 longitudinal study dataset was acquired from the National Center for Education Statistics. A logistic regression was run to determine the predictive value of residence on student persistence by census race group. The findings of this study reveal that residence halls are not accomplishing as much for Black and Latino students as they are for White students. The results of this study challenge PWIs to take additional steps to more fully commit the benefits of residence halls to Black and Latino students.

KEYWORDS: persistence; predominantly White institutions; Black; Latino; residence halls; residence; retention 


\title{
YOU BELONG HERE: RESIDENCE HALLS AS DISPARATE PREDICTORS OF SOPHOMORE YEAR PERSISTENCE AT PREDOMINANTLY WHITE INSTITUTIONS
}

JAMES RAYMOND NEVILLE

\author{
A Dissertation Submitted in Partial \\ Fulfillment of the Requirements \\ for the Degree of \\ DOCTOR OF PHILOSOPHY \\ Department of Educational Administration and Foundations \\ ILLINOIS STATE UNIVERSITY
}


(C) 2019 James Raymond Neville 


\section{YOU BELONG HERE: RESIDENCE HALLS AS DISPARATE PREDICTORS OF SOPHOMORE YEAR PERSISTENCE AT PREDOMINANTLY WHITE INSTITUTIONS}

JAMES RAYMOND NEVILLE

COMMITTEE MEMBERS:

Diane Dean, Chair

John Rugutt

Elizabeth Lugg

Levester Johnson 


\section{ACKNOWLEDGMENTS}

To those who have called me a student, I thank you for your guidance and mentorship.

To those who have called me a colleague, I thank you for your role modeling and dedication.

To those who have called me a mentor, I thank you for the trust you've placed in me.

To those who have called me a son, I thank you for the inspiration and support.

To the one who calls me her husband, I thank you for putting up with me.

To the one who calls me Daddy, I thank you for making me better.

J.R.N. 


\section{CONTENTS}

Page

ACKNOWLEDGMENTS

TABLES

FIGURES 2 vi

CHAPTER I: BACKGROUND 1

Introduction $\quad 1$

$\begin{array}{ll}\text { Statement of the Problem } & 1\end{array}$

Conceptual/Theoretical Framework 3

Purpose of Study \& Research Questions 4

Overview of the Methodology 4

$\begin{array}{ll}\text { Positionality Statement } & 8\end{array}$

$\begin{array}{ll}\text { Rationale } & 9\end{array}$

$\begin{array}{ll}\text { Chapter Summary } & 10\end{array}$

CHAPTER II: INTRODUCTION TO CAMPUS HOUSING AND RESIDENCE LIFE 11

History of College Student Housing 11

$\begin{array}{ll}\text { Origins } & 12\end{array}$

$\begin{array}{ll}\text { Extent of Application } & 20\end{array}$

$\begin{array}{ll}\text { Variety of Options } & 22\end{array}$

$\begin{array}{ll}\text { Organizational Structure } & 23\end{array}$

Applications of Foundational Student Development Theory 25

Evolution of Student Development Theory 25

College Impact Theory $\quad 34$ 
Applicability to Modern Students $\quad 38$

Research on Outcomes of Living in Campus Housing 42

Cognitive Outcomes $\quad 44$

$\begin{array}{ll}\text { Affective Outcomes } & 53\end{array}$

$\begin{array}{ll}\text { Disparate Impacts } & 60\end{array}$

$\begin{array}{ll}\text { Gaps and Limitations } & 64\end{array}$

$\begin{array}{ll}\text { Chapter Summary } & 67\end{array}$

$\begin{array}{ll}\text { CHAPTER III: METHOD } & 70\end{array}$

$\begin{array}{ll}\text { Overview } & 70\end{array}$

$\begin{array}{ll}\text { Research Design } & 70\end{array}$

$\begin{array}{ll}\text { Population and Sampling Procedures } & 70\end{array}$

$\begin{array}{ll}\text { Instrumentation and Measures } & 71\end{array}$

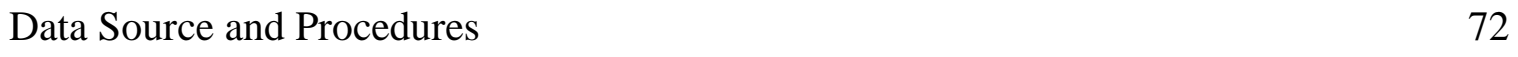

$\begin{array}{ll}\text { Data Analysis Procedures } & 73\end{array}$

$\begin{array}{ll}\text { Internal and External Validity } & 75\end{array}$

$\begin{array}{ll}\text { Chapter Summary } & 76\end{array}$

$\begin{array}{ll}\text { CHAPTER IV: RESULTS } & 77\end{array}$

$\begin{array}{ll}\text { Coding } & 77\end{array}$

$\begin{array}{ll}\text { Description of Sample } & 79\end{array}$

$\begin{array}{ll}\text { Findings } & 82\end{array}$

CHAPTER V: DISCUSSION

$\begin{array}{ll}\text { Introduction } & 86\end{array}$

$\begin{array}{ll}\text { Research Questions } & 87\end{array}$ 
Discussion

$\begin{array}{ll}\text { REFERENCES } & 97\end{array}$

APPENDIX A: BPS DATA FILE CODEBOOK 


\section{TABLES}

Table

Page

1. Demographic Frequencies of Sample $\quad 80$

2. GPA Frequencies of Sample $\quad 81$

3. Residence Frequencies of Sample $\quad 81$

4. Persistence Frequencies of Sample 82

5. Logistic Regression $\quad 85$

6. Frequency of Persistence by Race and Residence 93 


\section{FIGURES}

Figure $\quad$ Page

$\begin{array}{ll}\text { 1. Conceptual Framework } & 3\end{array}$ 


\section{CHAPTER I: BACKGROUND}

\section{Introduction}

Living in an on-campus residence hall has been shown to benefit the development and success of college students in a variety of ways. It promotes student satisfaction, social interaction, and ultimately makes the student more likely to persist into their second year. The primary causal vehicle of these benefits is the sense of belonging and community that students in residence halls enjoy. However, not all students feel the same sense of belonging in residence halls. Studies have shown that students of color at majority-White institutions report a lower sense of belonging than their White counterparts. This places the benefits of residence halls in jeopardy. The goal of this study is to compare the influence of residence hall living on student persistence between White students and students of color at predominantly White institutions.

\section{Statement of the Problem}

Higher education plays a unique role in the social, economic, and racial fabrics of the nation. Students that graduate with a bachelor's degree have been shown to enjoy a much higher earning potential over their lifetime when compared with those that do not. Completion of a four-year degree is rightly viewed as an entrance into a professional career. For many career paths, a degree is a requirement for entry-level positions. Consequently, college attendance is an important step toward individual economic prosperity.

As with any such opportunity, higher education holds an interesting relationship with systems of privilege. Campuses have long been welcoming to the privileged majority. Underrepresented groups, by contrast, have not enjoyed unfettered access to the halls of ivy. In some cases, these groups have created their own institutions, most notably in historically Black colleges and universities (HBCUs). Modern campuses recognize this history, and now view a 
diverse student body as beneficial to all students. Promoting the attendance and success of minority students is a top social justice goal for most predominantly White institutions (PWIs).

Today, debt also plays a significant role in a student's decision to attend college.

Between tuition, room and board, books, and other incidental costs, a college degree can cost a student tens of thousands of dollars. Counting on the prospect of future earning potential, a great many students take out large student loans to meet these costs. This raises the stakes for successful completion; if a student fails to complete their degree, they are burdened with significant debt without the accompanying degree to bolster their earning potential.

For all of the preceding reasons, completion of a four-year degree is critically important to modern college students. In addition, it is increasingly important to colleges and universities as well. Stiff competition from other institutions, lackluster state support, and performancebased funding metrics all compel institutions to retain the students that come to their campus. A poor retention level can cripple an institution, and a strong one can help it to endure other challenges. These concurrent factors make student persistence a consequential topic of study.

We know from theory that involvement, belonging, and engagement are critical factors to student success and persistence. Studies show that residence halls have the ability to affect student satisfaction and promote student persistence. However, some studies also indicate that minority students may not experience the same sense of belonging at PWIs as majority students. This potentially undercuts the causal links of the benefits of on-campus living. If true, then residence halls may only be places where majority-population students feel welcomed, and thus, where minority students do not enjoy the same benefits. The problem is that we do not know if living in a residence hall at a PWI benefits minority students in the same way that it benefits majority students. 


\section{Conceptual/Theoretical Framework}

Living in an on-campus residence hall provides undergraduate students with multiple opportunities and services. By virtue of living in a university-managed residence, they are freed from the responsibilities of cooking and cleaning, freeing them to focus on studies. Institutions offer many developmental services to students, including conflict resolution, behavior standards, academic support services, and counseling. These services prime students for success. Finally, they have the benefit of interacting with peers. Hopefully, in these peer relationships, students will find a sense of belonging and an opportunity for leadership development.

That final item, however, seems to be unreliable. Literature on the subject indicates that students of color may not feel the same sense of belonging in residence halls at PWIs. If this is true, then they may not experience the same level of benefits from this residence. In exploring this topic, this study will use this causal interaction as its conceptual framework. See Figure 1 below.
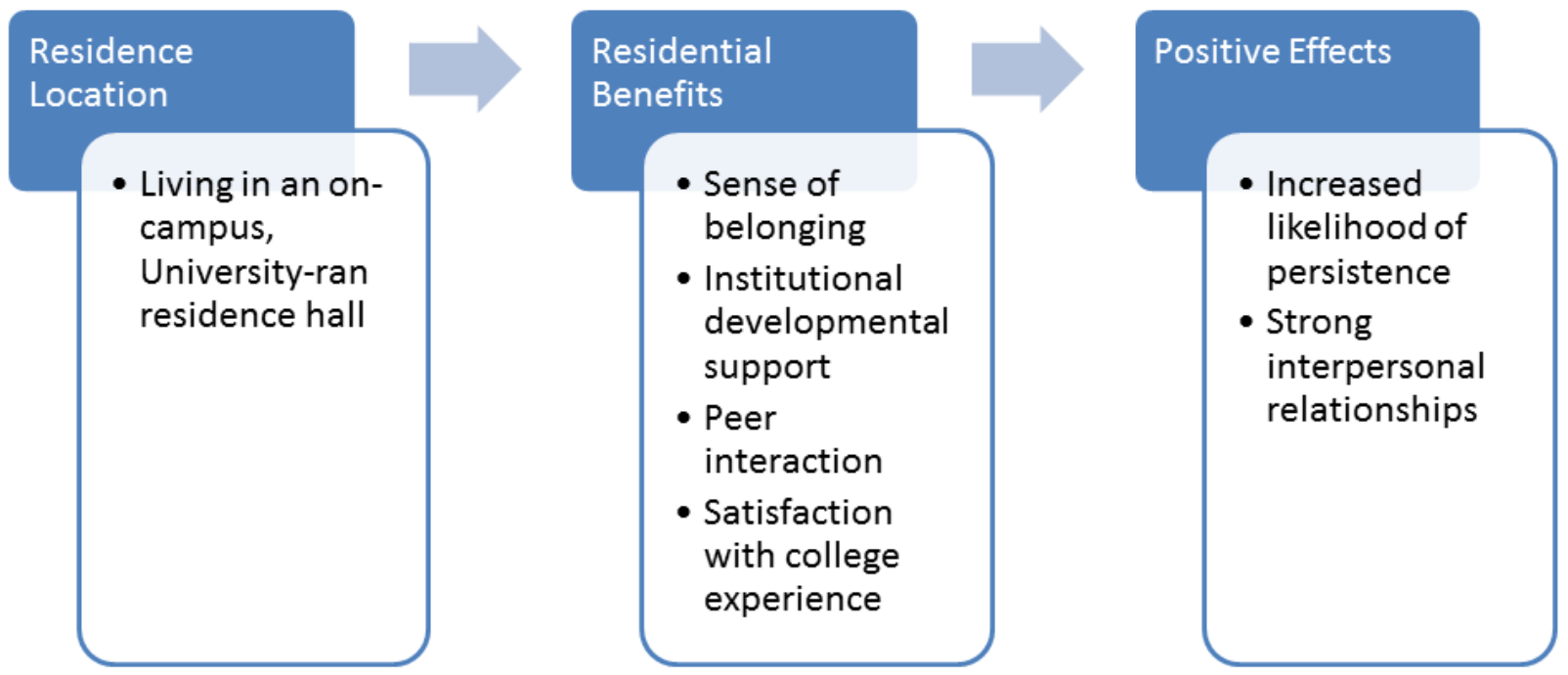

Figure 1. Conceptual framework. 


\section{Purpose of Study \& Research Questions}

The purpose of this study is to improve our understanding of residence halls' effects on diverse populations. Residence hall professionals aspire to provide welcoming and developmental communities for all students; however, there is a gap in the current literature regarding whether or not this is happening. To do this, persistence rates of minority students will be compared to majority populations when the contributing factor of residence is taken into account.

This study will seek to answer the following research questions:

1. Is living in a residence hall a significant determinant of sophomore year persistence at PWIs for students of all races?

2. How do the probabilities for persistence compare for students based on race?

\section{Overview of the Methodology}

Definition of study variables. This study will use the following terms:

Persistence - a decision made by a first-year student about whether or not to remain enrolled for their second year. A student can transfer to a different institution for their second year and still be considered to have persisted. This is a decision made at the individual level.

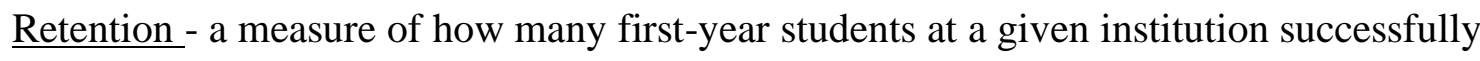
complete their first year and remain enrolled for their second year. This is a percentage rate that institutions track.

Sophomore Year - a student's second year of full-time enrollment in an institution of higher education. This term is used without consideration for the number of credit hours earned. 
Residence Hall - a dormitory owned and operated by an institution of higher education solely for its students. A residence hall is one option for students, along with fraternity or sorority houses, off-campus apartments, or living at home.

Definition of study terms. There are no terms used throughout this study that are likely to be incomprehensible to the average reader.

Data and data source. To best answer the research questions, this study will pursue quantitative methods. The most comprehensive and wide-ranging data set has already been collected. This study will use data from the Beginning Postsecondary Students (BPS) longitudinal study, which is collected by the National Center for Education Statistics (NCES). The BPS study incorporates data from a number of sources, including the expansive National Postsecondary Student Aid Study (NPSAS). This broad, national dataset is without comparison or equal. It will provide this study with the ability to answer the research questions on a national scale.

The key independent variables in this dataset are residency and ethnicity. The key dependent variable is whether or not the student persisted at the same institution for a second year. Confounding variables to be controlled for include family income, high school GPA, and student work hours. The extant literature indicates that these all have significant influences on student persistence. By controlling for them, this study will seek to isolate the effects of oncampus residence.

Limitations. This study, like any other, has its limitations. First, there is a legitimate question about the accuracy of any widespread survey. Unlike personally-conducted interviews, a large national survey does not allow for the researcher to have total control over the data from its creation. Surveys have notoriously poor response rates. There are also concerns about the 
truthfulness of reported data and any clerical errors that occur in the handling of such a large data set. Further, it is possible that those who are least likely to respond to the survey or comply with follow-up reports are the same ones that may be particularly influenced by the study variables. Because of this, a word of caution must be given to the reliability of the data. However, there is no better data set to use for this study. A survey conducted by one researcher cannot hope to match the sample size of the BPS data. In addition, because the sample was conducted by the NCES, any researcher can rest assured that adequate precautions have been taken to preserve the reliability of the data. Finally, the BPS data was collected through a variety of methods, including phone interviews, in-person interviews, and digital surveys. This was done to maximize response rates and accurately conduct follow-up tracking for individual cases. In short, the BPS longitudinal study is the best-quality data set available for researchers hoping to examine national trends.

Another limitation of this study is the assumption of a causal relationship. The use of certain statistical analyses presumes causality, and ignores the role of other factors. Although the literature is clear on the influence of residence halls, there other factors at play. The first year of college provides an environment that is rife with unpredictable elements, all of which could act as additional "treatments" for the purposes of the study. Experiences outside the scope of this study may affect a student's propensity to persist for their second year. Considering this, there is some risk in proclaiming that it solely the interaction of residence and minority status that accounts for any of the variance that may be detected. To address this issue, this study is considering a large amount of outside characteristics. A review of the literature reveals that the best studies have controlled for several personal characteristics that are known to influence student success. These same characteristics are listed as confounding variables in this study. No 
study can perfectly isolate the influence of a single variable, but this study has taken all possible steps in order to minimize outside factors.

On this topic, one known shortcoming of the data is its lack of descriptive residence hall information. Although unquestionably expansive (the BPS data includes over 1,200 variables for each case), this dataset does not note what type of residence hall a residential student resided in. Traditional residence halls, deluxe suites, and full apartment-style units are all categorized together. As will be shown later, these offer much different experience for residents. As a result, they could possibly affect the variable of student persistence. However, because relevant data does not exist, this question cannot be addressed in the context of this study.

The final limitation worth noting is its quantitative approach. Inherent within the method of using numbers is an inability to draw certain conclusions. No analysis of quantitative data, for example, can explain the reasons or the "why" behind a given phenomenon. It can identify trends and predict outcomes, but not reveal the motivation behind them. Consequently, this study cannot ascribe motivation to the students of its sample. It also cannot explain the experience of any given student. Because this study focuses on a large, national sample, it can only explain large, national trends. Its conclusions will only be accurate for that sample, and will not apply to any particular individual. This, of course, limits the application of this study. It would be inappropriate to use this study to alter the services or care for any single resident. Despite this, it is still a meaningful study that can broaden institutional understandings of the interaction between race and residence.

Delimitations. Some restrictions have been intentionally set. The first concerns the nature of the BPS 2012 cohort data. The data from the 2014 follow-up is now over five years old and has been available for some time. A final 2017 follow-up was conducted for the cohort, and 
includes data on graduation rates and employment. This study has chosen to use only the 2012 \& 2014 data. This is an acceptable limitation. Additional variables from the 2017 follow-up are not necessary to answer this study's research questions. Although no doubt intriguing, it would not be helpful in answering the research questions. In addition, the application and licensure process for acquiring BPS data is grueling, and without a compelling argument for needing such data, it was unwise to seek it. Even without the 2017 follow-up data, this dataset is still the largest, most comprehensive, and most recent dataset that is available to researchers. No new incoming cohorts of college students have been studied since 2012. Because its comprehensiveness cannot be matched by the data collection efforts of a single researcher, the 2012/2014 BPS data is still the most appropriate set to use for this study.

Some delimitations are also set in the use of the data. To answer the research question, this study will only be examining traditional-aged students at four-year, bachelor's degree institutions, and not community colleges. Further, this study will be focus solely on PWIs. This restriction is done intentionally. Although the dataset includes students from all universities, not all are needed. To accurately answer the research questions, the set must be pared down. This will isolate the populations that are being examined and make the results as clear as possible.

\section{Positionality Statement}

I have worked in the field of residence life since 2008. I have personally welcomed students into residence halls, counseled students in crisis, mediated conflicts, and fostered the growth of engaged and inclusive communities. I have found this work to be deeply rewarding. I have taken immense pride in the communities I have helped create, and I have relished the opportunity to assist undergraduates in discovering themselves. I am well-read in the theories of student development and student engagement, and I have witnessed their effectiveness when put 
into practice. As a result, it is fair to say that I believe in both the form and function of residence life.

However, since entering professional practice as a residence hall administrator, I have been troubled with lingering suspicions about my work. To be specific, I am uneasy about the way in which residence halls create a sense of belonging. In quiet moments of reflection, I worry that this work has not gone to benefit those who may need it most. I am concerned that I have created environments that are welcoming only to majority students, and do not equally welcome minority students. Although I hope I have helped all residents find a sense of belonging, I would be crestfallen if underrepresented students have not enjoyed the same benefits. With that concern in mind, I have embarked on this study.

\section{Rationale}

With this study, I hope to clarify the role that on-campus housing plays in persistence. Part of this, of course, is personal; I want to know if the communities that I have created have been beneficial for all students or just majority students. There is also an academic motivation. Such a study is necessary to examine the effects of residence hall living on students outside the majority. Some studies have tried to find disparate impacts on the cognitive effects of residence hall living, but a review of the literature shows that such effects are unreliable and disputed. An affective measure, such as student persistence, has been proven by the literature and makes an ideal variable for examining the role of race.

The answers to these research questions are consequential for the work of residence hall professionals, and for student affairs as a whole. As a review of history has shown, the role of residence halls is critical to the role of the modern residential campus. Housing departments operate as a microcosm of the student affairs field, offering some degree of student counseling, 
leadership opportunities, conduct management, and a venue for student engagement.

Professional organizations tout residence life as an avenue to promote student belonging and retention. To what degree these goals are realized for students of color is of vital consequence for practitioners. The answer to these research questions may compel residence life programs to better tailor services to underrepresented groups and intentionally foster inclusive communities.

Finally, this study can fill a gap in the literature. Living in a residence hall is widely acknowledged to promote student persistence by increasing a student's sense of belonging. However, some literature has also indicated that students of color at PWIs may not experience the same sense of belonging as White students. This hints that the benefits of residence halls may not be visited equally upon all students. Although some studies have looked at disparate benefits, none have examined the role of persistence. Such a study can fill this gap in the literature and further the field of knowledge.

\section{Chapter Summary}

The purpose of this chapter was to identify the problem and the purpose of the study. In addition, specific research questions and terminology definitions were provided. The proposed methodology was explored, as were the limitations and delimitations of the proposed study. The chapter concluded with a positionality statement by the author, and the rationale and necessity of the study. 


\section{CHAPTER II: INTRODUCTION TO CAMPUS HOUSING AND RESIDENCE LIFE History of College Student Housing}

Student housing in American higher education has been dynamic; it has developed and grown, both in physical structure and in theoretical rationale. Physically, the history of campus housing has paralleled the growth of colleges and universities. Spartan sleeping halls gave way to high-capacity high-rises, which have developed into deluxe residence halls that are rich with student-focused services.

Similarly, the theoretical history of campus housing has grown from proximal necessity and moralistic axioms to a fully developed set of theoretical frames and exhaustively researched study findings. Institutions of higher education found themselves concerned with the growth of the individual in a context outside of the classroom, and tailored their campuses to that purpose. In many locations, the focus given to student learning inside the classroom is matched by the focus given to student learning outside of the classroom.

The physical and theoretical growth of residence halls has been rewarded by a third kind of growth: enrollment and occupancy. As the modern campus has grown, so have the residential capacities of on-campus housing. This has been both a boon and a challenge; the rise in occupancy has made campus housing more visible, and consequently more susceptible to critique and calls for accountability. In addition, meeting the needs of modern students has proven to be a challenge.

The most obvious change has been linguistic; the appellation for campus housing buildings has shifted from "dormitory" to "residence hall" to match their purpose and function. Austere quarters for students are now venues of valuable extracurricular learning. An 
introduction to campus housing and residential life in higher education in the United States follows in the sections below.

\section{Origins}

As colleges and universities were founded, dormitories were an optional but not critical component. In the earliest iterations of American higher education, there existed no compulsion to provide lodgings for students. Even institutions that brought students from great distances (by virtue of their caliber or notoriety) did not have an obligation to accommodate students. This simply was not part of the role of a college. There was no social expectation for institutions to provide this service. Students understood that their lodgings were their own responsibility.

The concept of a campus dormitory was brought to American campuses by way of Germany (Blimling, 2015). German campuses traditionally provided sleeping dormitories for students. This mimicked the cloistering of monks at German monasteries, and possibly was designed to accomplish the same goals: to sequester students and minimize distraction from their studies. These buildings were not intended as places of activity. These dormitories provided a bed for students and nothing else. This history is visible in the terminology for these buildings. The German word "schlafsaal", which translates to "dormitory," is rooted in the word for "sleep" ("schlaf"), much in the same way that the English word "dormitory" shares the same root as the word "dormant." (It is worth noting that the modern German residential campus may refer to these buildings as "wohnheim" ["residence hall"] or "studentenheim" ["student's home."]) American academics that studied in Germany apparently enjoyed the concept, and brought it back to the U.S. By the mid-1800s, American colleges and universities were following the examples of Harvard and Yale and adopting the dormitory system, along with a variety of other ideas from German campuses (Blimling, 2015). 
Despite the proximity to campus, colleges and universities did not seek to exert control over their students. Their personal affairs and wellbeing were of no concern to the institution. Gregory Blimling succinctly describes the mentality of higher education at this time, noting that "faculty considered students to be adults and left them alone to resolve their personal problems. An educational philosophy focused on knowledge content and impersonal relationships with students became pervasive in American higher education" (Blimling, 2015, p.7). At this time, education took place solely in the classroom. Further, the role of the community was important to both college faculty and students. Budding scholars were expected to be involved members of the local community. After all, they were in the process of becoming the most academically elite members of society. It was only proper that they embed themselves in the local society, rather than retreat from it.

Two trends in higher education led to the growth of dormitories on American campuses. First, the expansion of land-grant colleges in the late 1800s created public institutions that were sometimes far removed from major metropolitan areas. Their students needed lodgings, particularly if there were no boarding houses in the nearby village. Several institutions used to require faculty members to board students in their homes; however, this strategy was inadequate for large or growing student bodies.

The second and more important trend was the growth in the educational philosophy of institutions. In the late 1800s, the rigid liberal arts curriculum was no longer appropriate for a growing nation. Exclusive studies in Latin, Greek, and Rhetoric were no longer in demand. Instead, students sought studies in topics that were directly relevant to their lives, and to the work opportunities that were available following the Industrial Revolution. In short, students sought a more practical application. The Morrill Acts that created land grant colleges reflected this by 
requiring applicant institutions to offer curricula for agriculture, engineering, and military science in addition to the classical studies (Thelin, 2004). This created a philosophical shift for higher education. Colleges and universities began to consider the education of the whole individual.

With this shift in philosophy came a shift in the administration of student affairs. Whereas faculty members were previously charged with the whole education of the student, institutions now began to see value in differentiating roles. Harvard College was the first to do so in 1890 when they named one of the faculty members the "dean of men," an act now widely seen as the first full-time student affairs position (Schroeder \& Mable, 1994; Blimling, 2014). This appointment was the first step into the creation of an entire profession. Contemporarily, it was merely an admission that the needs of students outside the classroom required more attention than had previously been paid.

In loco parentis. In the 1800 s and early twentieth century, education of the "whole individual" was synonymous with a moral education. Higher education willingly accepted this solemn task. Higher education administrators had begun to understand the society-shaping power that they wielded by way of their graduates. With this power, they sought to create a more just, scholarly, and refined culture. Prevalent educational philosophy at this time held that the "the moral charge [was] implicit in higher education," and that "a liberal education created the 'gentleman"” (Maxcy \& Maxcy, 1997, p. 45). Such a moral charge was not just present at religiously-affiliated institutions, but also at secular public universities. Consequently, in addition to their vocational studies, students received instruction in ethical standards and civic responsibility. 
By 1937, the field of student affairs had grown considerably. The once-lonely dean of men at Harvard College now had many colleagues in similar roles across the nation. Their job duties reflected the ways in which colleges and universities had grown and developed over the years. They supervised the application of scholarships, athletic groups, student organizations, dining halls, and dormitories. In 1937, the American Council on Education met to codify the philosophy behind the burgeoning field of student affairs. In the resulting document, "The Student Personnel Point of View," they laid out their shared purpose and vision for student services (American Council on Education, 1937). In the list of their specific objectives, modern student affairs administrators might find several agreeable goals, such as "Orienting the student to his educational environment" and "Providing and supervising an adequate housing program for students." Also included were objectives that modern administrators may find overbearing, such as "Supervising, evaluating, and developing the social life and interests of students" and "Supervising, evaluating, and developing the religious life and interests of students" (American Council on Education, 1937, p. 19). This reflected the paternalistic paradigm under which student affairs administrators operated at this time.

This paradigm is best described by the legal term in loco parentis, which is Latin for "in place of the parent." Under this paradigm, educators from kindergarten up were viewed as a stand-in for the child's guardian, and carried all the corresponding rights and responsibilities. Educators were free to use whatever strategies they felt were in the student's best interest, from corporal punishment to strict rules on socialization. The educator took full responsibility for not just the academic growth of the student, but also for their moral development.

In the context of campus housing, this manifested as a firm set of rules to govern the personal lives of students, as well as staff to monitor their behavior. Undergraduate students 
were housed by gender, and supervised by "housemothers" who gave instruction on manners, social courtesies, and proper dress (Blimling, 2015). Typical rules included prohibitions on opposite-sex visitors, daily curfews, and attendance at community religious functions. By today's standards, these rules are undoubtedly paternalistic. However, a better term may be "maternalistic," as most campus dormitories were directed by "female faculty, faculty widows, deans of women, and other mature female adults with good judgment who could be entrusted with the supervision of housing for students" (Blimling, 2014, p. 12). As late as the 1960s, the primary qualification and defining characteristic for dormitory administrators was not professionalism, but maternal instinct. Undergraduate students were wards of the institution.

This paradigm was challenged in the 1960s. The decade (and in particular the latter half) saw a great deal of social turmoil and activism. College campuses, as the home of politically conscious young adults, were the epicenter for this upheaval. Students demonstrated on campuses across the nation in protest against the Vietnam War and in favor of civil rights. Simultaneously, they balked at the overbearing rules provided by parental dormitory staff. Bedtimes, they argued, were not appropriate for young adults who were old enough to face mortal danger in Southeast Asia or on a bus in Alabama. In this environment, higher education administrators began to rethink the operation and purpose of dormitories. It is in this context that research-based practices began to emerge.

Student development. In 1975, the American College Personnel Association (ACPA) released a guiding document for this new paradigm titled “Tomorrow's Higher Education Project." In it, the organization laid out a rationale for embracing the guiding principles of student development, which it defined as "the application of human development concepts in the post-secondary setting” (ACPA, 1975, p.11). This rationale rested on the humanistic ideals of 
self-actualization and theories of behavioral development. The goal, as stated in the report was to create an environment conducive to individual growth, rather than forcibly controlling such growth (ACPA, 1975).

This coincided with an explosion of research-based theories on student growth and identity development. Alexander Astin, Vincent Tinto, and Arthur Chickering were among a flood of authors who helped shape a new rationale for student development. Universities widely accepted these theoretical bases, and incorporated them into their campus housing practices. These theories would become foundational to the field of student affairs, and they are examined in depth later in this chapter.

For some, this transition was difficult to accept. The argument that student affairs were equally consequential to the student experience as academic affairs struck some as presumptuous. Author James Penney (1969) referred to the profession of student affairs as "stillborn," and little more than "housekeeping activities" (p. 92). He argued that the work and philosophical goals of student affairs workers were "not among the major influences today in colleges and universities" and "will not be recognized or accepted as a vital aspect of the academic world" (Penney. 1969, p. 93). Robert D. Brown, the Vice President for Academic Affairs at the University of Nebraska in 1974, decried the proposed new vision of student affairs as "social engineering" and argued that universities should abandon campus housing altogether. He argued,

When the days of in loco parentis are completely something of the past, there will be no remaining justification for college and universities to be in the housing business. Unless residence halls can be shown to have some educational value, they should be in the hands of private enterprise or student cooperatives. (1974, p. 44) 
One might argue that these detractors were too firmly ensconced in comfortable old ways to accept the changes to the field. In any case, Robert Brown's premise was proven false; residence halls were shown to provide substantial benefit to college students. The nature and extent of these benefits will be covered fully near the end of this chapter.

By the 1970s, student development became the dominant theoretical core of student affairs work, and practitioners across the nation received promotions from "dean of women" to "vice president of student affairs" (Blimling. 2015). Simultaneously, the name "dormitory" was discarded in favor of "residence hall." The implicit message in this shift is that the buildings and their staff had more to offer students than just a place to sleep. Following the model of academic areas, residence halls began offering a residential curriculum comprised of events and programs focusing on conflict resolution, independent living, and diversity/inclusion. Institutions also sought to blur the lines between academic affairs and student affairs. Offerings for themed floors increased, where all residents share the same major, courses, and post-college goals. The physical growth of residence halls paralleled the growth in mission, and they became complex buildings with elaborate systems of plumbing, electricity, elevators, and telecommunication cabling.

The modern residence hall. Physically, the modern residence hall is designed to meet all the needs of students. In addition to a bedroom, residents typically enjoy a common area or lounge, a front desk with mail services, and rooms for group meetings or studies. High-end residence halls may provide a workout room with exercise equipment, computer labs with printing stations, dining halls with national restaurant chains, or even more extravagant resortstyle amenities. Nearly all are wired with elaborate fire detection and suppression systems, cable television, and wireless internet. These amenities are par for the course. 
Administratively, the buildings are designed to educate students outside the classroom. Buildings are often staffed by full-time, live-in, master's degree-level student affairs professional. They employ a variety of assistants, including student resident assistants (RAs) who directly manage smaller subsets of the building. Residential curricula vary by institution, but often charge the residence hall staff with providing a variety of social, educational, and philanthropic programming to students.

These buildings are deeply intertwined with the larger student affairs network. It is common for residence hall staff to collaborate with professionals in the counseling office for a student that is experiencing mental health issues, with the academic support center for a student struggling with their studies, or with the bursar's office for a student with questions about billing. Residence hall staff members often serve as conflict mediators, conduct officers, event planners, vandalism investigators, and guidance counselors, even if there is a specific department on campus for that role. In this way, residence hall staff could be considered a "jack of all trades" in the student affairs field.

However, not all of the roles of residence hall staff exist in harmony. For example, the difficult task of disciplining a resident may be at odds with the goal of providing a welcoming and liberating experience for students. In addition, any time spent managing the administrative tasks of a building is time not spent improving the student experience. Gregory Blimling (2015) has developed a theoretical model to guide residence hall administrators in defining and shaping their residence life curriculum. He encourages administrators to plot their departmental goals on a triangle, with one end representing student learning, the second representing student administration, and the last representing student services (Blimling, 2015). Such a definition can be necessary for institutions that find themselves torn between customer service and student 
development. Although students consistently demand modern buildings with great amenities, the philosophical goal of student development remains the same. This friction is exacerbated by an environment of institutional competition for admission and retention.

Competition is far from the only dilemma faced by present-day residence life programs. Currently, many are struggling with the needs of transgender and nonbinary students, and exploring options related to gender-neutral housing options. Such a conversation elicits the same kind of concerned hand-wringing from parents and donors that coeducational residence halls elicited fifty years ago. Additionally, residence halls have been subjected to additional scrutiny as a result of funding challenges. As state support for higher education institutions has waned, universities have become acutely aware of the need for frugality and performance (Blimling, 2014). The field of student affairs has seen marked growth over the last two decades, and has been subject to criticism for "administrative bloat." As a result, residence life programs are frequently charged with providing high quality service at reasonable costs. These dynamics continue to develop as each successive generation of students arrives.

\section{Extent of Application}

As noted earlier, residence life programs rely on research that shows that living in an oncampus residence hall is beneficial for students. For that reason, most major colleges and universities require at least first-year students to live in university-owned residence halls (Kuh, Kinzie, Schuh, \& Whitt, 2005). Some extend this requirement to two years, or even all four years of undergraduate education. In practice, this means that the majority of on-campus residents are 18 to 24 years of age.

Some campuses also offer housing options for populations other than first-time students. Married students, students with dependent children, transfer students, and military veterans are 
the typical populations to whom these options are aimed. These students may desire to live oncampus for the convenience and proximity, but may not desire the traditional residence hall experience. University-owned options for these students are less common.

National occupancy data shows that a substantial portion of the U. S. population resides in residence halls. Unfortunately, there is no comprehensive survey of the full capacity of all residence halls from every college and university. Surveys have been created by various professional associations, but response has been voluntary and therefore incomplete. However, reliable occupancy data can be found from the United States Census Bureau. Using census data, the U.S. Census Bureau (2015) estimates that over 2,660,000 students reside in college or university housing as of 2015 . Of this population, approximately $46 \%$ are male and $54 \%$ are female. As anticipated, 96\% of campus housing residents are between the ages of 18 and 24 . The Census Bureau further reports that $74 \%$ self-identified as White, $13.6 \%$ as Black or African American, 9\% as Asian, and 9\% as Hispanic or Latino. Approximately 44\% reported residing at the same address in the prior year, and 53\% reported living at a different address (U.S. Census Bureau, 2015).

From this data, it is apparent that the demographics of college residence halls are roughly representative of the population as a whole. The U. S. Census Bureau (2015) estimates that, as of $2016,77.1 \%$ of the population self-identified as White, $13.3 \%$ as Black or African American, $5.6 \%$ as Asian, and $17.6 \%$ as Hispanic or Latino. Further, they reported that $29.8 \%$ of the nation's population has a four-year degree or higher (U.S. Census Bureau, 2016). Given the prevalence of on-campus housing requirements, one can deduce that a substantial portion of the population has some experience with residence halls. 


\section{Variety of Options}

Campus residence halls come in a variety of styles. The traditional style is the doubleoccupancy room, or the double. Although each student is given their own bed, desk and storage area, the small size of the room forces them to share the space and learn to interact with a roommate daily. The room opens directly to a communal hallway. Twenty or more doubles are arranged on the same floor, resulting in floor communities of 40 to 60 residents. A communal bathroom including toilets, showers, and sinks is typically located in the hallway and available to all residents of the floor. A small lounge area may be provided on the floor for events or quiet study. Traditional style rooms are by far the most common type of university housing, outnumbering all other types (ACUHO-I, 2015). Other variations of the traditional type may include singles, triples, and quads.

Suite-style rooms provide another option for on-campus residents. Like traditional rooms, they may offer single-occupancy or double-occupancy bedrooms. In a suite, one or more rooms share a common space lounge with a bathroom, providing more square footage and more privacy for the residents. Such rooms are often less common on campuses, and are eagerly snatched up by groups of friends. These rooms are offered at an increased room rate to students, highlighting their exclusivity. The "deluxe double" is a variation on the suite-style, where two doubles are connected via a small private bathroom (in a home, this would be referred to as a "Jack and Jill" bathroom).

Pod-style rooms take the advantages of both traditional rooms and suites. In pods, a cluster of multiple-occupancy rooms and bathrooms are recessed from the hallway, creating the impression of a private area. Unlike suites, the area in this pod is fully accessible from the hallway; there are no doors to close it off. Since more students live in a pod than in a suite, there 
is a greater chance that residents will be in a pod with someone they do not know, rather than an insular group of friends. Pods are helpful at creating smaller subsets of residents out of a large floor, assisting students with socialization.

Colleges and universities also offer apartment-style units, which feature full kitchens or kitchenettes, fully private bathrooms, and additional common space. These rooms are frequently reserved for upperclassmen or family housing, as they provide maximum privacy and inhibit community development. For this reason, and for their increased cost to build and maintain, apartment-style units are rarely used for on-campus housing.

An emerging trend in campus housing is the public-private partnership (P3). In a P3, the university partners with a private corporation or housing provider in order to provide lodging for students. Emergency P3 relationships may be forged between local hotels and universities in order to house students in the event of a natural disaster or structural failure. Universities may also seek P3s in order to finance the construction of a new residence hall. Finally, institutions may seek a P3 in order to house an unexpected surge of incoming students, turning a onceprivate apartment complex into an official provider of university housing. In effect, this designates an already-existing building as an acceptable venue to house students that would otherwise be required to live in university housing. In all of these scenarios, the management, finance, and operation of the residence life curriculum is negotiated as part of the relationship. Either party could become "silent partners," ceding the responsibility to the other. Alternately, the public and private institutions may share duties based upon negotiated terms.

\section{Organizational Structure}

Campus housing departments take a variety of shapes and styles. The variance in organizational structures is largely due to the variance in institutions; elements such as campus 
size, institutional mission, public or private ownership, and departmental needs can all shape the structure of housing departments. In addition, institutional history and traditions can also be consequential. In short, each department has a number of influences that shape the organizational structure. Common themes and compositions are described below.

Nearly all residence life programs rely on students themselves to provide the first tier of support and guidance. Selected students are trained in residence hall policies, conflict mediation, and crisis response. They serve as resident assistants (RAs) (although the title varies by institution), typically in exchange for a waiver of room and board costs. These students may or may not be official "employees" of the institution; identical RA position descriptions may be classified as a job at one institution and a "leadership role" (similar to a student organization member) at another. These RAs are tasked with creating welcoming communities in residence halls, and forging a sense of belonging among disparate groups of students. In a concrete way, this entails mediating roommate disputes, assisting with adjustment to college, enforcing university policies, referring residents to campus services, hosting floor events, and building relationships with residents.

These RAs are typically supervised by professional or paraprofessional staff that manage a building or complex of buildings. These hall directors (HDs) tend to be full-time bachelor'slevel or master's-level professionals at large public universities, and graduate students at small private colleges. HDs are almost always required to live in the on-campus buildings that they supervise (ACUHO-I, 2015). HDs lead and supervise the student development efforts in the residence halls. They also manage the administrative tasks of residence life, including budget management, student conduct adjudication, facility upkeep, crisis response and follow-up, and record-keeping. 
Depending on the size of the on-campus population, additional staff may support and supervise the live-in HD and RA staff. A department director may be aided by units that manage room assignment, themed communities, facility management, information technology, budget management, or a host of other ancillary tasks. Conversely, these duties may alternatively be conducted outside of the housing department. For example, a campus facilities department may service all buildings, including the residence halls, or a facilities unit within the housing department may service just the residence halls.

A nonstandard yet common approach is the bifurcated system, which separates the duties of housing and residence life. In such a system, two separate departments manage the oncampus housing experience. Student development tasks, such as building programming and managing student wellness, are handled by the residence life department. The housing department manages all of the administrative tasks, including facility maintenance, room assignment, and billing. Such bifurcated systems implicitly argue that the work of student development merits the undivided attention of one singular department, and that extraneous administrative tasks only distract from the mission at hand.

\section{Applications of Foundational Student Development Theory}

\section{Evolution of Student Development Theory}

In 1856, University of Michigan president Henry Tappen expressed his opposition to oncampus housing, stating, "The dormitory system is objectionable in itself. By withdrawing young men from the influence of domestic circles and separating them from the community, they are often led to contract evil habits and are prone to fall into disorderly conduct" (as cited in Blimling, 2015, p. 7). In this sentiment, Tappen was a product of his time. Popular sentiment, however, has shifted significantly. Student success and the value of residence halls have been 
topics of scholarly study for nearly 50 years. The findings and theories of these researchers have been immensely influential. Several of the authors that initially explored this field have now risen to notoriety, and their writings have inspired several generations of scholars.

The work of four noteworthy authors has shaped student development theory. Their theories have guided the field of student affairs and given specific direction to residence life programs. Their theories give colleges and universities the tools to significantly affect who students become. Through targeted action, higher education professionals can transform a student's personal and educational outcomes. These theories and strategies are both applicable and effective today. Despite the tectonic changes that have occurred since these theories were developed, they remain valid.

Alexander Astin. The first and foremost author of student affairs is Alexander Astin. Astin (1984) provides a theory of student success that has resonated in the context of residence halls. This theory, the student involvement theory, provides an explanation for student outcomes. Student involvement, Astin argues, is the best predictor of the student's likelihood of successful academic outcomes and connection with the institution. Astin defines involvement as "the amount of physical and psychological energy that the student devotes to the academic experience" (1984, p. 518). Researchers and practitioners would later use the similar word "engagement" to more accurately describe the active nature of this energy.

This theory was instantly framed in terms of practice; as soon as it was presented, Astin (1984) argued that "the effectiveness of any educational policy or practice is directly related to the capacity of that policy or practice to increase student involvement” (p. 519). Ever since, student affairs professionals around the nation have used the writings of Astin to defend their programs. 
Astin's theory provided structure and purpose to the field of study. Prior to this time, research had been unmoored from a reliable theoretical frame. Astin (1984) admits as much, stating in his introduction that he sought "to bring some order into the chaos of the literature... I am increasingly bewildered by the muddle of findings that have emerged from my own research" (p. 518). His work had the intended outcome. His has become the dominant theoretical lens through which student affairs research is conducted. His are the works that are assigned reading for prospective college professionals.

Involvement and engagement, therefore, is the goal to which Astin urges practitioners to commit. Academic studies, student organizations, athletics, and social circles are all viable vehicles for this involvement. Astin (1984) notes that residence halls in particular are ideal venues to foster widespread campus engagement. "Living in a dormitory," he noted, "is positively associated with several other forms of involvement: interaction with faculty, involvement in student government, and participation in social fraternities or sororities" (p. 525). Because they provide communal living in close quarters, residence halls provide a natural impulse to build strong relationships among residents.

Adherents to Astin's theory are consequently proponents of heavy student engagement efforts. They seek to sign students up for a bevy of affinity groups and student organizations. They provide students with opportunities to volunteer in the community. They bring noteworthy public figures to campus for lectures, and they host interesting events on campus. They encourage students to get to know their instructors outside of the classroom and interact with them informally. Most importantly, they provide a suitable environment for students to interact and engage with each other. Such actions are closely tied to the actions of residence life professionals. 
Vincent Tinto. The work of Vincent Tinto provides a second vital perspective on the student development. His model of student retention helped to create structures that promote student success. Tinto (1975) cast doubt upon the assumption that the students who left college were merely "dropouts" who could not muster the academic abilities needed to persevere. Instead, Tinto argues that those students who leave the university are those that are least involved, invested, and integrated into the campus community. In other words, they feel no sense of affinity for the institution, and no sense of belonging. Tinto argues that, in most cases, student attrition is predominantly caused by "the problems of adjustment to college life, to the issue of congruence between the individual and the institution, and to that of isolation from the life of the college" (Tinto, 1993, p.82).

Tinto asserts that both student affairs and academic affairs have a role to play in counteracting these harmful trends. For the academic side, Tinto urges colleges to assist students with goal-setting and planning. Lack of clear expectations can have a profoundly dispiriting effect on students, as can a lack of direction (Tinto, 2012). He asks colleges and universities to find strategies to help first-year student to select courses, undeclared students select majors, and first-generation students to know what to expect from baccalaureate studies (Tinto, 2012). Such steps, he argues, can help students chart their course through college and adjust to the demands of college life.

Tinto's model also has implications for student affairs. In this model, social isolation is fatal to persistence in college. If a student does not feel like they have a place at the university (socially or intellectually), they are more likely to leave. The appropriate response, then, is to promote connectedness. Tinto (1993) asserts that, "Other things being equal, the greater the contact among students, the more likely individuals are to establish social and intellectual 
membership in the social communities of the college and therefore the more likely they are to remain in college" (p. 118). To that end, student affairs professionals are challenged to foster a strong sense of belonging, both on a small scale (such as the floor community of a residence hall) and on a large scale (as with the institution as a whole).

Like Astin, Tinto believes that life outside of the classroom is a consequential factor for college and university students. In another parallel with Astin, Tinto has become recognized as a foundational author in the field. This theoretical frame is frequently used by a multitude of researchers. In a very real way, their theories are two sides of the same coin; Astin argues that involvement is critical for student success, and Tinto argues that lack of involvement results in student attrition.

The implications for residence life programs are clear. Tinto's model challenges residence hall professionals to seek out isolated students and cultivate their connection to the college environment. It challenges them to promote a sense of communal belonging within their buildings. It challenges them to make every student feel welcome and valued. Every student should feel like a member of at least one group, whether it be a social circle or an interest group. Doing so can help to stymie student departure from college.

Arthur Chickering. Arthur Chickering's research into student development provides a third basis for the work of student affairs. In seeking to model the development of students of traditional college age, Chickering offered his theory of identity development, which is now frequently referred to as his seven vectors of development (Chickering \& Reisser, 1993). These vectors represent the developmental milestones and ongoing struggles that students experience. They are presented below, with brief explanations of Chickering's meaning: 
1. Developing competence. Students must seek intellectual, physical, and interpersonal mastery.

2. Managing emotions. Anger, guilt, and sexual desire should be harnessed and safely directed, so that they do not consume and control the student.

3. Moving through autonomy toward interdependence. The student must feel a sense of self-determination and be free from the need for affirmation, yet still connected to others in society.

4. Developing mature interpersonal relationships. Students should be able to develop interact successfully with others, force deep relationships, and demonstrate an appreciation for differences.

5. Establishing identity. Students should be able to withstand criticism, define themselves independently, and express comfort with their various identities.

6. Developing purpose. Students should know what they want to accomplish in life, and how they want to accomplish it.

7. Developing integrity. The student should be able to develop and demonstrate a set of personal values. (Chickering \& Reisser, 1993)

Chickering's vectors highlight the steps toward maturity and adulthood that students typically take during their time on college campuses. These are instructive for residence life professionals, as it tells them what to look for in student growth. As educators, these professionals seek to promote the development of students. As proprietors of campus buildings, they seek to provide a safe setting for this development to occur.

Chickering's vectors have received some measure of criticism from researchers and practitioners (Jones \& Abes, 2013, p. 35). Some scholars argue that the ways in which 
individuals master these vectors is highly dependent upon their gender, race, and ethnicity. As a result, they argue, these vectors are not entirely applicable to diverse populations. This has inhibited the wholehearted adoption of Chickering's model in the context of student affairs. It remains, however, an influential model for tracking student progress.

Nancy Schlossberg. Nancy Schlossberg's transition theory provides the fourth and final foundational theory on which student development rests. Unlike the vectors of Chickering, Schlossberg's theory is not a model for human development. Instead, it is a guide for professional counselors to assist adults through difficult and even traumatic transitions. The transition theory holds that there is comfort in predictability, and that any transition in one's life results in some measure of change. As a result, transitions can be a source of stress and anxiety (Anderson, Goodman, \& Schlossberg, 2012). The death of a loved one, for example, may impose a transition upon someone. A move to a different living arrangement is another obvious example. Becoming a college student and commencing a rigorous course of study is another. The transition theory holds that, when faced with a transition, an individual's response depends on four major factors (also known as the four Ss). They are:

1. The situation (e.g., is the transition anticipated or unanticipated, temporary or permanent)

2. The self (e.g., the influence of the individual's constitution, resolve, and ego)

3. Social support (e.g., what networks of care the individual has, and their access to support resources)

4. Strategies (e.g., the coping mechanisms the individual uses, and their strategies to resolve or move through the transition) (Anderson et al., 2012) 
These factors determine how successfully the individual will navigate the transition with which they are faced. According to this theory, a multitude of variables contribute to the outcome. For example, an individual challenged with a relatively minor and temporary transition (situation) may find themselves unable to cope if they are poorly prepared (self), separated from family and friends (social support), and unwilling to ask for assistance (strategy). Conversely, what one individual sees as an intractable situation may be of little concern to another.

Even though the transition theory was not specifically intended for undergraduate education, it was nonetheless adopted by student affairs practitioners. The transition theory is applicable to most major life changes, and a student's transition to college is assuredly significant. Schlossberg noted that the theory was not intended for developing adolescents, but rather for adults aged 18 and over (Anderson et al., 2012). While one may argue whether or not 18-year-olds qualify as "adults," it is the age at which traditional-aged students enter college. For that reason, student affairs professionals have appropriated it.

On broad scale, colleges and universities have incorporated Schlossberg's transition theory into many programs and services. The most obvious is student orientation. By bringing students to campus early, the institution seeks to slowly acclimate them to campus life, and minimize their transitional anxiety. Students are provided with information and materials all support services, including counseling, tutoring, financial aid, and local transit options. Students are explicitly told to use these services in order to assist with their transition to college. Staff members walk them through the process of registering for courses and escort them to campus dining halls and activity centers. In addition, some universities offer bridge programs for academically marginal students. As the name implies, such programs offer a firm structure to help students cross the gap to their collegiate careers. Students are brought to campus before 
courses begin and given supervision on how to study and how to spend time outside of class. The aim of such programs is to give supplementary, high-touch support to students who would otherwise be at risk of mismanaging the college transition.

The transition theory challenges residence hall programs ask what support systems are provided to new incoming students. Hall staff members are present at a critical juncture in their transition. Although the university cannot minimize the adjustment to college life (situation) nor alter the inner resolve possessed by a student (self), it can provide students with emotional and academic support services (social support) and encourage them to use such services (strategy). Hall staff are in the best position to help students manage homesickness and difficulties associated with communal living. In addition, concerted action from hall staff can assist students in feeling welcomed and enmeshed in the campus community. Even indirectly, residence halls assist with college adjustment. The presence of other first-year students in a communal environment sends the implicit message that the college transition is not suffered alone. In these ways, residence halls and their embedded professionals provide the support for which Schlossberg advocates.

Separate and combined, the theories and models offered by Astin, Tinto, Chickering, and Schlossberg have guided the work of residence life programs. Their work has given purpose and direction to the field. These works have provided the rationale for student development, which has become the defining paradigm for on-campus housing post-in loco parentis. Today, departmental missions are specifically shaped to promote student involvement, foster a sense of belonging, develop students' identities, and assist with their college transition. These same goals are promoted as best practices and core missions by a consortium of professional organizations 
(Council for the Advancement of Standards in Higher Education, 2014). Grounded in these theories, residence life programs seek to promote the success of students.

\section{College Impact Theory}

While the previous theories explain the predictors of student success, other concepts explain how the college environment can actively affect change in students. These concepts help to explain the method by which colleges and universities alter the development of students. They give student affairs professionals the necessary tools to do so. An exploration of these concepts reveals that residence halls have the capacity to alter student development.

In addition to providing a basis for student development, Alexander Astin also provided one such causal framework. His framework has come to be called the I-E-O model (Astin, 1993). This acronym stands for input, environment, outcomes. This framework holds that all educational and personal outcomes are a factor of both the student input and the college environment. Further, it states that the college experience is a moderating variable in the student outcome equation, and that the inputs play a significant role. The term "inputs," in this context, refers to the specific characteristics of a student prior to entry into college, including academic ability and personal drive. Some students may be inadequately prepared, or lack the determination to complete a rigorous course of study. Some are prone to spend more time on recreational activities and intoxicating beverages than their studies. In other words, not every student is destined to succeed, regardless of the supportiveness of the environment. Conversely, many students have such determination and strength of character that they are able to overcome any setback. For these students, even negative college experiences would provide little deterrent for matriculation. 
In the context of this framework, "environment" refers to all the events, courses, social groups, faculty, peer interactions, and residence hall environments that a student experiences during their time in college (Astin, 1993). These variables are mostly under the control of the institution, and as such could be considered independent variables. It is in these that institutions hold the key to affecting student outcomes. Residence halls provide a significant part of the student environment, both literally and figuratively. The majority of a student's time not spent in class will be spent in a residence hall (Levine, 1994; Blimling, 2015). With such access to students, campus housing has the ability to significantly shape a student's time in college. This environment, then, helps mold the type of student that graduates from the institution.

Astin's I-E-O framework has echoes of Schlossberg's transition theory. The same variables that Schlossberg categorizes as "self" and "support" factors would be categorized by Astin as "input" and "environment" factors. Both of these models agree that the attention received from residence hall professionals is integral to student success. Further, both agree that targeted support can help students overcome what would otherwise be inadequate personal preparation. As a result, there is a strong defense for the argument that residence halls can shape student outcomes.

Pascarella and Terenzini (2005) have adopted and modified Astin's framework. Like Astin, they argue that the college experience does affect students. These effects, they argued, could be measured quantitatively. They took the I-E-O framework and applied it for use in six separate applications:

1. Verbal, quantitative, and subject matter competence

2. Cognitive skills and intellectual growth

3. Psychosocial change 
4. Attitudes and values

5. Moral development

6. Educational attainment and persistence

7. Career and economic impacts of college

8. Quality of life after college (Pascarella \& Terenzini, 2005)

By conducting a meta-analysis of all extant research on college outcomes, they concluded that college does have a significant and measurable effect on student outcomes. As with quantitative study, they encouraged researchers to take appropriate steps to isolate the variables to be measured. Knowing that student inputs have effects, they encourage researchers to control for variables such as high school grade point average, family income, and other confounding variables (Pascarella, Terenzini, \& Blimling, 1994). Such factors, they argue, are known to be strong predictors of success in college, and all studies seeking to measure residence hall effects should compensate for their influence.

Researchers are divided on whether residence halls' method of influence is direct. For example, Blimling (2015) argues that the value of residence halls rests in the experiential learning that they provide to students. He argues that students gain critical social interaction skills by virtue of the exposure and repetition they get in residence halls. The residence halls offer a variety of interpersonal and academic experiences that help student to stretch their abilities and test their efficacy. Other offerings, such as student government positions, philanthropic activities, and leading a floor as an RA can also provide experiential learning. “These experiences,” Blimling asserts, “teach functionally transferable skills such as organization, working within policy structures, civic engagement, cultural awareness, and management skills" (2015, p. 71). Others argue that residence halls, by virtue of their grouping 
of students, "help connect and create smaller campus communities to ameliorate the potentially overwhelming physical and psychological size of campus" (Kuh et al., 2005, p. 107). Following this concept, residence halls parse students into smaller groups in order to prevent them from feeling awash in a sea of humanity. Still others argue that the best outcomes are realized by incorporating academic studies into the residence environment (Kuh, 1994). They argue that themed communities, academic interventions, and an ethos of support are what make residence hall living an opportunity for growth. All of these conceptions are based on the premise that residence halls directly influence students.

There are also a substantial set of scholars and researchers who believe the benefits of residence halls are conferred indirectly. One argument is that residence halls merely provide the venue for beneficial outcomes, and that their effects are passive rather than active (Pascarella, Terenzini, \& Blimling, 1994). In this explanation, residence halls are like a Petri dish that provides a nurturing medium for the growth of students, but they do not directly shape their growth. A similar argument is posited more colorfully by Arthur Levine (1994). Only somewhat facetiously, he notes that he personally learns a great deal about international events each time he visits his dentist, but only because he reads the Foreign Affairs magazine in the waiting room (Levine, 1994). Residence hall professionals, in Levine's coy analogy, are the dentists. Although they conduct an ambitious enterprise, the real value comes from all the events outside of university control: late night conversations with friends, personal struggles with time management, and the search for individual purpose. As Levine (1994) notes, "The educational outcomes of residence life... occur almost incidentally on many campuses, rather than by design" (p. 94). Such a view still holds residence halls as important, but as settings rather than as instructors. 
Regardless of the method, the extant research is unanimous that residence hall living is consequential in shaping student development (Astin, 1993; Blimling, 2015; Pascarella \& Terenzini, 2005). Residence hall administrators hold a position of exceptional influence. They can shape the experiences of residents, who spend the majority of their day in on-campus housing. Such significance warrants further research.

\section{Applicability to Modern Students}

The aforementioned models and theories of student development are persuasive, but most have their roots in the 1960s and 1970s. During that time, cutting-edge residence halls offered party lines for telephone service, and only the most liberal institutions had young men and women housed in the same building. One may rightly question whether these theories are applicable to today's undergraduate student. Rather than obsolete, the foundational theories of student development are more relevant than ever to the work of student affairs. Although the current crop of undergraduates has notable differences from previous generations, these differences only make the work of student affairs professionals more vital.

The students currently pursuing their undergraduate education fall in the hazy space between clearly-defined generations. Those born between 1980 and 2000 are frequently referred to as millennials (DeVaney, 2015), and those after 2000 have most frequently been referred to as Gen Z (Dimock, 2019). There are a number of traits that are positively attributed to those born after 1980, including optimism, a passion for civic engagement, and a favorable attitude toward teamwork. Several negative traits are also attributed to them as well, including a sense of entitlement, need for significance, and a lack of independence (DeVaney, 2015). This lack of independence has significant repercussions for the higher education setting. In college environments, some practitioners have reported that today's students have inadequate conflict 
management skills, and have parents that are highly involved in their day-to-day lives (Dickerson, 2007). This parenting style, which has been derogatorily titled "helicopter parenting," inhibits the growth of the individual by maintaining parental control over the student's life (Vinson, 2013).

This type of parenting presents a real challenge to the work of student affairs. Helicopter parenting impedes growth whenever a parent conducts a task that the student could or should conduct for themselves. Anecdotes of this type of parental behavior include completing college applications on behalf of their children, contacting faculty to contest a student's grade, and sitting in on job interviews (Vinson, 2013). In the setting of a residence hall, this behavior may take the form of a parent notifying residence hall staff about a roommate conflict between their student and the student's roommate, requesting immediate resolution of the conflict, and asking to be kept apprised of their child's comings and goings. This is unhealthy behavior that prevents adequate development. Further, it circumvents the work of student affairs professionals. If this behavior were demonstrated between two romantic partners rather than a parent and child, a counselor might refer to it as a toxic relationship.

These challenges make the work of student development that much more important. As presented earlier, student involvement, engagement, and belonging are critical factors to success in college. A student cannot be meaningfully involved in the college if they are not making their own educational decisions. A student cannot be truly engaged in the college community if they must video call their parent every night. They are unlikely to find a sense of belonging on campus if they are unable to work through conflict. So long as their parent fights their battles for them, their vectors of development are stalled. For these reasons, student affairs professionals must demonstrate their commitment to student development by redoubling their efforts. 
Residence hall professionals must assess their residents and, through targeted intervention, build their conflict management skills, decision-making abilities, and coping skills. They must help residents to build their own identity. This does not mean that colleges must sever their residents' parental bonds. Rather, it means that student affairs professionals must help students transition to college, and transition to adulthood.

Parents, too, need assistance transitioning. Although colleges and universities have not typically viewed their students' parents as a significant constituency, increased contact from parents has surely made it more apparent. In response, colleges and universities have taken steps to harness and redirect the enthusiasm of parents (Dickerson, 2007). At one time, it would have been unthinkable to have parents attend orientation along with their student. However, it is now a generally accepted practice to invite them to join. This is not done so that parents can supervise their student's transition, but instead to transition the parent (Budny, Paul, \& Newborg, 2014). Like the bridge program for academically marginal students, this orientation can serve as a bridge to independence for students. Parents are strategically separated from their students and told about the transition issues and independence that their students will enjoy, and encourage them to manage their own affairs. Meanwhile, the students are placed into groups with other students and allowed to create their course schedule. Free from the gaze of their parents, this separation allows students to socialize and exert a measure of autonomy (Budny et al., 2014). In this way, the university promotes a level of healthy distance and frees students to take their first steps into higher education unaided.

Much has also been made about the modern student's ubiquitous use of technology. By virtue of growing up with the assistance of cell phones and social media, they are often referred to as digital natives (DeVaney, 2015). This title conveys that students are fluent in the language 
of modern technology, and are immersed in the services it provides. In one sense this is certainly a good thing; having students that wholeheartedly embrace technologies can promote the cycle of innovation and discovery. Such technology, however, can also hinder the developmental goals of residence halls. If a student is socially engaged in a digital world, their engagement with the physical world is suppressed. Remaining fully connected to one's home life can numb the necessary transition to college life. A review of research on college outcomes led Matthew Mayhew and a team authors to this exact conclusion. They reasoned, "residents may be psychologically and physically less immersed on campuses today, given the proliferation and use of technology for communicating frequently with off-campus friends and family" (Mayhew et al., 2016). There is a real concern amongst researchers and practitioners that digital natives will struggle to immigrate to the college environment.

As with parental involvement, this trend highlights the vital role of student development professionals. Rather than rendering the work futile, the task of connecting students and fostering engagement is that much more important. Dickerson (2007) has noted that technology can have an isolating effect, which can manifest as roommates communicating solely through text message or social media, even while they are in the same room. Residence hall practitioners can attest that such anecdotes are not uncommon. In spite of this, the need to create a sense of belonging and foster personal development remains. Rather than swimming against the current, student affairs professionals have embraced technology and social media. At every level from the RA to the vice president for student affairs, social media and applications are used to connect residents to the university community. To foster involvement, residence hall professionals take intentional steps to promote in-person communication. Residents are encouraged to resolve conflicts face-to-face, and staff host conversational events on topics like diversity, politics, and 
current events. Communal programs are held to get residents out of their rooms and into social spaces. Although food is often used as a bribe for attendance, the real purpose is to build relationships among residents. These efforts can bolster student involvement in the campus community, and benefit developmental outcomes.

For the preceding reasons, residence halls are critically important components to serving millennial and Gen Z students in colleges and universities. Residence halls are ideally positioned to provide connection, integration, and engagement for students that to be socially isolated. They are also the best candidates to assist residents and their parents with the college transition. This task is not new for these professionals. Residence halls have been housing and serving millennial students for several years. If one assumes that millennials are defined as those born between 1980 and 2000, then the last traditional-aged millennial student arrived in their residence hall in 2018. As the hazy transition between generations plays out on campuses, residence hall professionals will continue to connect and assist students in their transition.

\section{Research on Outcomes of Living in Campus Housing}

In what is arguably Alexander Astin's most influential piece of writing, he confidently asserted that "Students who live in campus residences are much more likely than commuter students to become less religious and more hedonistic" (1984, p. 524). One might argue that such a proclamation reveals more about the author than the subject. This was apparently an area of concern for Astin; the word "hedonistic" or variations thereof appears five times in his 10page article on college outcomes. Astin's work in seeking to understand the outcomes associated with living in on-campus housing joins a rich field of research. Researchers have been specifically focusing on this area since the 1960s, and they have found a variety of interesting results. 
In addition to providing foundational theories for student development, Astin also provided a tool for categorizing student outcomes. While seeking to sort the outcomes enjoyed by residents, Astin (1973) applied a behavioral sciences lens. In this " $2 \times 2$ taxonomy," Astin posited that all student outcomes can be measured in a four-square grid. One axis has the terms cognitive and affective, and the second axis has the terms psychological and behavioral. These axes intersect to create a grid of four squares. Into this grid, Astin placed various characteristics and personal growth vectors. For example, Astin (1973) placed "academic achievement" in the cognitive-psychological cell and "interpersonal relations" and "choice of major" in the affectivebehavioral cell. This taxonomy has been frequently used by other researchers since Astin appropriated it.

This taxonomy provides a clear way to categorize the literature surrounding the study of residence halls. Two concurrent themes are present in the study of on-campus housing's effects on students, and they follow Astin's first axis of the taxonomy: cognitive and affective outcomes. A cluster of research has focused on outcomes such as GPA and critical thinking, and others have focused on actions such as drinking behavior and student persistence. These trends in the literature offer a clear picture of the significance of residence halls.

Pascarella and Terenzini (2005) offer a different method for categorizing student outcomes, but it will not be used here. In their hefty book How College Affects Students, they sorted student outcomes into eight groups: Verbal, quantitative, and subject matter competence; Cognitive skills and intellectual growth; Psychosocial change; Attitudes and values; Moral development; Educational attainment and persistence; Career and economic impacts of college; Quality of life after college. While comprehensive, this system lacks the beauty of simplicity. It was designed to assess the effects of higher education as a whole, and not just the on-campus 
housing component. Further, it incorporates dynamics that are not relevant to the study of residence halls; no researcher, for example, has yet claimed that residence halls affect a student's career choice. Consequently, this system is inappropriate for use in the study of living oncampus.

In the following sections, I will assess the state of research on residence hall outcomes. I will do this by first compiling the results of the previous 50 years of research. I will categorize this research according to Astin's cognitive/affective taxonomy, revealing that one thread of this research is much more consistent than the other. I will then assess studies that explore the theme of disparate impact. Next, I will critique the extant research by exploring limitations and other methodological concerns. Finally, I offer a case for the future study of the disparate outcomes of living in residence halls.

\section{Cognitive Outcomes}

In categorizing this literature trend as cognitive outcomes, I appropriate the taxonomy used by Astin (1973). He described cognitive outcomes as "measures [related to] behavior that requires the use of high-order mental processes such as reasoning and logic" (Astin, 1973, p. 111). As a result, I will use this terminology to describe any research that focuses on critical thinking, views on diversity, academic performance, and college satisfaction. Scholars of this theme have typically focused on the intellectual growth and development of students as a result of their time in residence halls. The arguments for this growth are fairly evident; residence halls not only surround students with peers and fellow budding scholars, but also ensconce young adults in the campus community. Further, they provide young adults with food, shelter, custodians, and service staff, removing a multitude of distractions and freeing students to focus on their studies. 
When examining this theme in totality, the research is mixed. Some studies have found evidence of cognitive influences of on-campus living, but others hold on-campus living as inconsequential in this regard. These disagreements have not been resolved. As a result, there is no consensus on whether living in a residence hall can meaningfully act upon residents' cognitive development.

Early research. Early research into the effects of living on campus seemed to be clear. Researchers expressed certainty that residing in on-campus dormitories was capable of significant cognitive influences on students. Many expressed a belief that the proximity to faculty and laboratories led inexorably to beneficial academic gains (Astin, 1984; Chickering, 1974b). These arguments focused around the convenience enjoyed by residential students. With all of their needs for food and shelter met, they argued, students were freed to concentrate on coursework. This argument implicitly characterized the university campus as a black hole; those who were physically closer to the center were subjected to stronger academic forces, and those who orbited further away experienced a lighter pull.

The argument for the cognitive influence of campus housing also extended to the social and political spheres. As noted earlier, Astin (1984) at one point believed that living on-campus was correlated with an abandonment of religion and the adoption of a hedonist lifestyle. Other research pointed toward a shift in ideological views. Arthur Chickering (1974b) declared that "students who live at home are more frequently conservative and those who live in college dormitories are more liberal (p. 66). He conducted a series of surveys on "hot button" issues of his day, and found stark differences. Dormitory residents were more likely to advocate for social change, and less likely to believe that poor people have the ability to lift themselves out of poverty. Dormitory residents were more likely to have favorable views toward both communism 
and racial integration. They were also more likely to advocate for the legalization of cannabis than students who lived at home (Chickering, 1974b). With these results, he concluded that oncampus housing caused the change in cognitive outlook. Drawing on his own developmental theories, Chickering posited that the cause of this change was the access to communities of learning enjoyed by on-campus residents. The residence hall community offered formative experiences and diverse interactions.

Critical thinking. As research matured, the results became muddier. An excellent example of this can be found in outcomes associated with critical thinking. Modern studies that seek a correlation between on-campus housing and critical thinking development have received mixed findings. A typical set of findings are presented by Inman and Pascarella (1998), who conducted pre- and post-test surveys of first-year college students. Their data suggested that residence halls were inconsequential. In their words, "residence during college did not significantly contribute to the explained variation in the end of freshman year critical thinking" (Inman and Pascarella, 1998, p. 13). In other words, separate distinct variables were likely responsible for first-year student cognitive growth.

This thread has been picked up by several authors, including Gregory Blimling (2015). Blimling furthers the field of knowledge by helping to define and measure these separate distinct variables that contribute to growth in critical thinking. Past academic performance and preexisting critical thinking skills were chief among these. Once these and other variables were controlled for, there was no evidence to suggest residence halls alone had a significant effect on the development of critical thinking. Pascarella (2005) agrees, noting that the main source of outside-the-classroom intellectual growth came from university programming initiatives, and not 
place of residence. These studies indicate that residence halls are not necessarily places of intellectual growth.

Several comprehensive meta-analyses have interpreted the extant research as uncertain. Pascarella and Terenzini (2005) state that, from the period of 1990-2000, "the evidence pertaining to the direct effects on generation cognitive growth of living on campus... is mixed and generally inconclusive" (p. 197). A decade later, Mayhew and others were able to point toward some newer studies that positively associated critical thinking gains with living on campus, but then also highlighted others that suggested a negative association (Mayhew et al., 2016, p. 135). Given this thorough analysis, definitive conclusions cannot be drawn regarding critical thinking in residence halls.

Diversity. On a residence hall floor, students of a variety of racial, cultural, and religious backgrounds come together to live in close proximity. This is a critical time to learn about others. It is also a wonderful opportunity to challenge preconceived notions. For those that come to college from homogenous communities, it could be the best chance to deeply interact with people different from themselves. Residence halls offer diverse communities that are artificially-created yet meaningful. Because of this, they can potentially provide residents with developmental experiences.

Conceptually, researchers have shown this causal link is borne out by the data. Several authors have shown that diverse experiences can reduce prejudice and promote the consideration of other points of view (Dovidio, Kawakami, \& Gaertner, 2002; Nagda, Gurin, \& Johnson, 2005). Through exposure to people from other cultures, students can change the way they feel about issues of diversity and the perspectives of others. These studies, however, did not include university residence halls. They were conducted irrespective of residence. Although they 
endorse the types of environments that residence halls create, they cannot be said to directly praise the role of on-campus housing.

Research that considers the role of residence halls is, however, mixed. Gary Pike (2002) used a single-institution questionnaire to survey college students, and found a positive relationship, concluding that "living on campus [is] directly associated with significantly higher levels of openness to diversity than living off campus" (p. 629). In considering the results of Pike and others, Pascarella and Terenzini (2005) confidently reported that living in a campus residence hall promoted attitudes of inclusivity and acceptance of racial diversity. These studies appear to validate the conceptual theories. However, at least one study has found conflicting results. By analyzing the data of a large, multi-institution longitudinal study, Padgett, Johnson, and Pascarella (2012) found that living on campus may not always benefit attitudes toward diversity. Their quantitative results suggest that first-generation students living in a residence hall are actually less likely to express appreciation and comfort with those from different cultural backgrounds. Although these results appear to contradict the findings of others, the authors reasoned that they were actually in line with expectations. They surmised that the first year of college can be a disruptive and unsettling experience, and that some students may feel resistance and negativity before ultimately welcoming the diversity of others (Padgett et al., 2012). Despite this clever rationalization, the data speaks for itself. There is a factual question as to whether life in residence halls can make a student more open to issues of diversity.

In total, one cannot conclude that residence halls make students more accepting or inclusive. Although there is a strong conceptual argument to be made, the study of direct effects has yielded conflicting results. The difference in results may be due to the difference in methods 
and sample sizes. Solid methods have been used in both, and additional studies are unlikely to resolve the conflict.

Academic performance. A vibrant disagreement exists in the literature regarding the role of residence halls in student academic performance. There is an assumption that, when considering the foundational student development theories, these theories imply that living oncampus can improve academic outcomes for students. This assumption is widespread, and for some institutions, has become the main rationale for requiring students to live in residence halls (Araujo \& Murray, 2010). In this context, academic performance is exclusively measured via student grade point averages (GPAs). Various studies using various methodologies have come to different conclusions.

A number of studies point toward the benefit of residence halls. This has typically been measured via the differential effects within the same institution. In one notable example, Araujo and Murray (2010) used a custom survey with residential students at Indiana University - Purdue University Indianapolis. They found that on-campus residents were more likely to receive better grade point averages than their peers who never lived in residence halls. They cited Astin as an inspiration for their study, drawing a connection between residence hall programming and the campus involvement advocated by Astin. Using a different design, Kanoy and Bruhn (1996) focused on the differential benefits of building type. They found that first-year students who lived in a themed building (where all residents share the same major and attend at least one course together) completed their first year with higher grade point averages than student who spent their first year in a traditional residence hall. They tied these results back to the theories of Tinto, writing "residential programs... can provide students with a greater sense of community than they might otherwise experience" (Kanoy \& Bruhn, 1996, p. 20). Such results speak to the 
benefits of themed communities and their ability to potentially blur the line between academic and residential buildings. In an even more targeted study, McClusky-Titus and Oliver (2001) found that the strength of the community in a themed residence hall can have a statistically significant effect on student academic achievement. The strength of community was measured using a tool that gauged their interpersonal involvement and sense of belonging on the floor. Studies such as these show promise for the influence of residence halls. All focused on the differential effects of populations at the same institution.

Studies that examined effects between institutions found conflicting data. Several studies have been unable to find any difference in student GPA that is attributable to place of residence, after controlling for factors like self-reported involvement, high school performance, and various institutional characteristics (Nelson Laird \& Cruce, 2009; Peters et al, 2018; Pike, Schroeder, \& Berry, 1997). These studies used large data sets that tapped institutions nationwide. They were also fastidious about controlling for other confounding variables. In most cases, the authors asserted their belief that residence halls were beneficial (perhaps for the secondary benefits they offered). However, they were unable to show that their mere existence was beneficial in itself. As a result of studies like these, all comprehensive meta-analyses are unwilling to conclude that living in a residence hall will benefit student GPA (Blimling, 2015; Mayhew et al., 2016; Pascarella \& Terenzini, 2005). A typical and oft-repeated analysis is that the evidence is "far from conclusive" and that living in a residence hall is "not likely to have an appreciable influence one way or the other on a student's academic achievement" (Pascarella et al., 1994, p. $30)$.

However, this conflict is not intractable. Although the studies appear to be at odds, they can potentially be reconciled when considering the type of residence hall community. If one 
accepts that the residence hall experience can influence a student's academic achievement, then it must logically follow that stronger communities lead to better outcomes than weaker communities. In other words, residential communities with high levels of social trust and positive decision-making could provide a more fertile environment than a residential community that is distrustful and uproarious. In this regard, the presence of themed communities may provide the answer to the differences in research results. As Blimling (2014) notes, when compared to traditional residence halls, themed communities "have more positive social climates and students exhibit stronger feelings of institutional belonging" (p. 96). A closer review of the research reveals that studies showing positive academic outcomes did, in fact, include themed communities (Kanoy \& Bruhn, 1996; McCluskey-Titus \& Oliver, 2001), and those showing no significant differences did not (Nelson Laird \& Cruce, 2009; Pike, Schroeder, \& Berry, 1997). This analysis does not, of course, lead inexorably to a conclusion that themed communities are the sole determinant of such benefits. It does, however, provide one possible explanation to the discrepancy in the literature.

Satisfaction. Standing in contrast to other areas of cognitive research, a consensus has emerged that residence halls can have a clear effect on student satisfaction with their college experience. This area of research is closely tied to dissatisfaction or stress. These two emotions are on opposite sides of the spectrum, and can both be present in student housing. Such emotions can be an obvious precursor to the sense of connectedness and belonging advocated by Tinto (1993). A review of the literature shows that residence halls have a strong role in the development of stress and satisfaction.

First and foremost, the role of roommate relationships is recognized as critical. A severe and persistent conflict with a roommate can be an obvious inhibitor to a sense of connectedness. 
In a survey of students from a Midwestern university, Ross, Niebling, and Heckert (1999) found that roommate conflicts provided one of the common sources of stress for undergraduate students. Stern et al. (2007) went even further, using a survey study to determine that students with good roommate relationships have a higher level of satisfaction with their university. They asserted that "roommate relationships are shown to have the single greatest impact on students' college experiences. Students' dissatisfaction with their roommates may lead to negative perceptions of their entire university experiences, and it is associated with lower retention rates and grade point averages" (Stern et al., 2007, p. 53). These studies imply that the quality of the social atmosphere in residence halls can have direct effects on student stress and satisfaction.

In addition, the physical atmosphere of residence halls has been a topic of research. Although omitted from the writings of Astin and Tinto, subsequent researchers have determined that the maintenance of the residence hall space plays a role in the student's perception of the university. Dusselier et al. (2005) found that the residence hall environment "played a prominent role in the amount of students' self-reported stress" (p. 22). Foubert, Tepper, and Morrison (1998) examined the residence hall space from the opposite angle of student satisfaction. They found that the physical quality of the residence hall was the most significant determinant of student satisfaction (Foubert, Tepper, \& Morrison, 1998). These studies point to general upkeep and visual quality of residence halls as harbingers of student satisfaction. In this way, the very existence of a residence hall can alter a student's affinity for the environment. This dynamic was found by Krafft (2014). Using a series of professional surveys, Krafft found that residents who found their buildings to be more aesthetically pleasing had a greater rate of institutional commitment (2014). 
Such studies on residence-related satisfaction and stress have been unified. A thorough analysis of the extant literature revealed no studies that implied residence halls were ineffective or inconsequential variables in student satisfaction or stress. From this, one can conclude that the residence hall environment has a significant influence on student satisfaction.

In conclusion, the state of cognitive effects of residence halls is conflicted. Notwithstanding the clear role that residence halls play in student satisfaction, the literature is mixed on the role they play in the growth of critical thinking skills, attitudes toward diversity, and academic performance. This review casts doubt on the ability of residence halls to alter the thinking of resident students. As a result, one must conclude that the evidence of cognitive effects of on-campus living are mixed and inconclusive.

Despite these findings, prominent authors still hold that the value of residence halls is critical, even if difficult to measure. Blimling (2015) asserts that "the evidence of the educational value of living in traditional residence halls is overwhelming" (p. 25). This faith is shared with others. Pascarella and Terenzini (2005) write that, despite "little consistent evidence that living on campus directly influences general cognitive growth during college... we suspect that it probably does exert an indirect, positive influence on general cognitive growth" (p. 198). In short, the most noteworthy authors of the field believe that college residence halls contribute to the intellectual growth of students, even if they cannot prove it directly. They maintain hope in a beneficial influence on residents' cognitive abilities, but it has been difficult to pinpoint.

\section{Affective Outcomes}

In stark contrast, the field of study on affective outcomes from residence halls is consistent. As with the previous theme of scholarship, the term affective outcomes is used as described by Alexander Astin (1973). He frames these types of outcomes as "observable 
activities of the individual" (Astin, 1973, p. 112). I will expand this definition slightly to include all behaviors, whether directly observed or self-reported. In total, then, the theme of affective studies will include any that seek to measure students' drinking behaviors, relationships, life experiences, or persistence through college. Authors of this field argue that students typically reside in residence halls during a particularly formative time of life. Consequently, they argue that residence halls have significant determinative access to young adults.

Early research. As with early cognitive research, early affective research yields a strong belief that on-campus housing can dramatically alter the behaviors of undergraduates. Arthur Chickering led the field in this area. Using the lens of his own theories, he argued that the social nature of residence halls allows students to collectively develop along their vectors in tandem. He supposed the vehicle for this was late-night dormitory conversations. While poignantly reminiscing about his own personal "college bull sessions," Chickering reasoned that dormitories promoted friendships among students (1974a, p. 77). Chickering continued to follow this line of thought, arguing that dormitories allowed students to find marriage partners, which promoted their success after college (1974a). The effect on interpersonal relationships was further studied by Brown, Winkworth, and Braskamp. In their titillatingly-titled article "Student Development in a Coed Residence Hall: Promiscuity, Prophylactic, or Panacea?," they found that living in close proximity to the opposite gender made men prone to dress nicer and women more conversational (Brown, Winkworth, \& Braskamp, 1973). Questions regarding undergraduate morals were further plumbed when Chickering examined the differences in behavior of residential students. He found that residence hall students were more likely than those living elsewhere to participate in a Vietnam war protest, less likely to say grace before meals, and more likely to listen to rock music (Chickering, 1974b). 
These studies gave the first methodologically sound indication that the residence hall environment could have affective outcomes for students. Though undoubtedly colored by the concerns of their day, they opened a line of inquiry into how student behavior changes. Modern research into this question has done little to change the belief that residence hall living can be consequential.

Interpersonal relationships. Interest has been sustained in the degree to which changes in interpersonal relationships are attributable to living in residence halls. Some authors have focused on individual growth, while others have retained the moralistic hand-wringing that is present in research from the 1970s. For example, two researchers from Brigham Young University conducted a study, and noted with concern that their results suggested coed floors resulted in more sexual encounters for undergraduate students than single-gender buildings (Willoughby \& Carroll, 2009). Although the authors of this study were worried by these findings, they shared the belief that the design of residence halls could influence this behavior.

In a more general sense, the literature is unanimous that residence halls allow for more contact between students and staff (Blimling, 2015). Whether by virtue of their proximity to campus or the collegial atmosphere they foster, researchers have shown that students who live in residence halls have more frequent contact with faculty members, and are more likely than offcampus students to interact with them informally (Pascarella et al., 1994). Although the authors were unable to pair these results with an observed increase in student GPA, they nevertheless touted the influence that the residential environment provided. They further found that oncampus students were much more likely to get involved with social groups and student organizations, and also much more likely to use campus facilities (Pascarella et al., 1994). These results are easy to conceptualize. Inside of residence halls, students enjoy long periods of 
unstructured time, and have the freedom to interact with others. Frequently, these interactions are prodded by residence hall staff through social programming. Students that commute to campus or live in private apartments do not enjoy such opportunities.

Blimling (2015) offers a novel explanation for the friend-making potential of residence halls. Students tend to gripe about the minimal square footage they are afforded when living in university housing. Blimling highlights this as a feature and not a flaw. "The design of many conventional RHs [residence halls]," he reveals, "facilitates [social] interaction by minimizing private space and inviting students into public spaces where interaction with others is most likely to occur" (2014, p. 204). By his argument, the somewhat-uncomfortable density of residence halls is the key to the social affective changes of residents. They cannot help but interact with others as they pass in the hallway, brush their teeth shoulder-to-shoulder, and share meals in the dining hall. This frequent interaction leads to demonstrated increase in friends and social circles. This dynamic is unique to university residence halls.

Alcohol use. For the same reasons, some authors have pointed toward residence hall layout as a contributing factor in student alcohol consumption. Cross, Zimmerman, and O'Grady (2009) took up this topic by administering two separate surveys to residence hall students. They were sure to control for pre-college drinking behaviors. Using residence hall room type as a variable, they measured the frequency of student drinking and the severity of negative alcoholrelated consequences. They found that students in apartment-style rooms were more likely to consume alcohol and more likely to miss class or do poorly on exams due to alcohol consumption than were students in traditional rooms. With these findings, they argued that the floor plan of a residence hall can significantly influence the alcohol consumption behavior of undergraduate students (Cross, Zimmerman, \& O’Grady, 2009). 
Undergraduate students do not need much encouragement to engage in risky alcohol consumption. It is well-known that American college students are prone to high levels of binge drinking. Although a fraternity house is the residence type that best predicts binge drinking behavior, drinking is still widespread throughout colleges; one study found that nearly half of all surveyed male students and a substantial minority of female students qualified as "binge drinkers" (Wechsler, Dowdall, Davenport, \& Castillo, 1995). Quantitative research suggests that the residence hall environment may contribute to this behavior. Using data from the Harvard School of Public Health College Alcohol Study, researchers Harford, Wechsler, and Muthén (2002) compared students living in coeducational residence halls, in single-gender residence halls, and with parents off-campus. They found that living on-campus was correlated with higher consumption, and that living in coed residence halls was correlated with more severe negative consequences of that consumption. To their benefit, however, the study also found that living in campus residences halls correlated with a lower probability with drinking and driving (Harford, Wechsler, \& Muthén, 2002). These studies offer clear evidence that the residence hall environment can alter the drinking patterns of residents.

At least one recent study points to the social nature of residence halls as the cause for this drinking behavior. Using online surveys of first-year students, they found that there was a strong correlation between student drinking behavior and the drinking behavior of their immediate peer group (Eisenberg, Golberstein, \& Whitlock, 2014). They found a natural experiment for this interaction in the roommate pairings of campus residence halls. They supposed that the friendmaking effects of residence halls had a secondary effect of promoting and spreading binge drinking behavior. The college environment is ripe for such an interaction. They observed that "binge drinking is more likely to exhibit large peer effects, because in college settings drinking 
frequently takes place in social contexts with many peers... [and] heavy drinking has relatively low stigma in college-age populations" (Eisenberg et al., 2014, p. 127). The residence hall, it seems, creates a favorable environment for the spread of behavior-altering trends.

Persistence and retention. One of the most thoroughly-explored subgenres of research in the affective theme is the relationship between residence halls and student persistence. Various authors point to living learning communities, residence hall programming, or sense of belonging as the causal link between these two variables. Regardless of reason, the research is consistent (Tinto, 2012). Pascarella and Terenzini (2005) succinctly summarize the unanimity of the research, stating "students living on campus are more likely to persist and graduate than students who commute" (p. 421).

At this point, some definitions are due. Although the words persistence, retention, attrition, and graduation can all be used to describe the difference between completing a degree program versus dropping out, there is an important distinction. Hagedorn's (2012) description is most succinct. She distinguishes between the first two, noting that “'retention' [is] an institutional measure and 'persistence' [is] a student measure. In other words, institutions retain and students persist" (p. 85). This definition, although clear, becomes confused when discussing the various types of retention. Tinto (2012) acknowledges that the first year of college is critical for students, and that a student who persists through their first year is likely to complete their degree. However, a student may leave college at any time. For the sake of clarity, I adopt Tinto's (2012) distinction in terminology. Persistence and retention are used to describe student actions between the first and second year of college, and attrition and graduation are used when describing whether or not a student completes their baccalaureate degree. 
A review of the literature shows that the residence hall experience is critical in promoting student persistence. This result stems from a variety of factors. DeAngelo (2014) used a firstyear student survey from the Higher Education Research Institute, and, after controlling for student background characteristics, found that the academic mentality promoted by on-campus living was a significant driver of second-year persistence. Non-human environmental factors were also found to be a contributor to persistence by Krafft (2014). Krafft issued multiple surveys to first-year students at a small liberal arts college, and found that satisfaction with the aesthetics of the residence halls increased student satisfaction and predicted persistence. Still other studies have shown that the increased involvement, campus activities, and socialization opportunities provided by residence halls are drivers of institutional retention rates (Blimling, 2015). This research is consistent that residence halls can affect this behavior. The closest thing to an outlier is provided by Astin and Oseguera (2012), who note that not only does living in a residence hall promote student persistence, but it also is positively correlated with the likelihood of the student to graduate four to six years later, even if they only reside in a residence hall for their first year.

The most methodologically rigorous study on this effect is provided by Schudde (2011). Using the 2002 cohort of the Educational Longitudinal Study (ELS) and merging it with the Integrated Postsecondary Education Data System (IPEDS), Schudde created a nationwide dataset that included a wide array of student data. Schudde controlled for the pre-college characteristics that are known to be predictors of student success, including high school GPA, family income, type of institution attended, and parental education level. By conducting various analyses, Schudde found that living in a campus residence hall gave first-year students a $3.3 \%$ increase in their probability of persisting to their second year (2011). Schudde's study has been widely 
lauded by the most prominent authors in the field as the best analysis of this topic to date (Astin \& Oseguera, 2012; Blimling, 2015; Mayhew et al 2016). It further solidifies the role that residence halls play in student persistence behavior.

These findings are so pervasive and consistent that practitioners have come to rely on them. When seeking to increase first-year student persistence, the University of Pittsburgh turned to these research-grounded strategies. A chronicle of these efforts and their success is presented by Brooks (2010). Service projects, living learning communities, and a residence hall curriculum were all part of these efforts. Persistence increased by $1.7 \%$, and although there was no empirical data to suggest this increase was directly attributable to these efforts, Books (2010) felt comfortable naming the residence life program a "major player," a "contributor," and a "coordinating force" to the institution's overall success (p. 22). Such is the unanimity of the extant research.

The state of the research on the affective outcomes of residence hall living is clear. Scholars have found time and again that living on-campus in a university residence hall has undeniable consequences on a student's conduct, behavior, and persistence. Although some researchers have disagreed on the morality of these consequences, none have denied their existence. As a result, this field can be considered a "closed case." Although research continues on the nature of these effects, it seems clear that a successful residence life program can and will alter the behavior of undergraduate students.

\section{Disparate Impacts}

While the previous trends in residence hall research seem vibrant, the theme of disparate impacts appears to still be developing. This theme asks whether separate populations benefit equally from the residence hall experience. In this theory, demographic factors such as gender 
identity, age, ethnicity, or sexuality may act as modifying variables to the residence life equation. Such a possibility was identified in the early 1990s by Pascarella, Terenzini, and Blimling (1994). In providing avenues for future research, they posited that "students' individual characteristics may frequently determine the magnitude of the educational impact of college residences" (Pascarella et al., 1994, p. 42). Under such a theory, it is plausible for disadvantaged populations to benefit less, or perhaps not benefit at all, from living in a residence hall. Similarly, traditional methods of stimulating student involvement may not reach all students equally. This diversity-conscious theme of research seeks to test the limits of research on residence halls. Clearly, this theme of research has important implications for practitioners.

It is worth noting at this juncture that race is a social construct and not a definable set of biological traits or propensities. One cannot identify the race of an individual by their genetic structure or thought patterns. The racial titles of "Black," "Asian," and "White" are constructed based off of arbitrary determinations, and not scientifically determined. For this reason, there is no scientific classification of race. Since it is socially constructed, however, it does have real consequences. Since social structures tend to segregate individuals and provide drastically different lived experiences, they can lead to differing effects in health, development, and behavior. In short, the classification of race does not have an inherent effect, but it is consequential because of societal effects. Therefore, the study of disparate impacts of college is a legitimate one. Astin's I-E-O model holds that college outcomes are a factor of both the student inputs and college environment (1993). The factor of race can introduce a socially confounding variable into the student input, moderating the effect of the treatment environment.

Scholars of this theme of research have taken a variety of approaches. One representative example of this type of research can be found in the work of Long (2014), who focused on the 
cognitive effects of male and female students. This study looked at student GPA, and compared students in residence halls with students in fraternity or sorority houses. Although both genders experienced a significant drop in GPA when moving out of the residence halls, male students suffered a GPA drop that was five times the magnitude of that of female students. According to Long (2014), these findings suggest that "on-campus housing appears to be a better residential environment for supporting the academic success of college men” (p. 77). A similar approach was taken by Ruth López Turley and Geoffrey Wodtke (2010). They conducted a similar study, but looked for differences in terms of ethnicity. They compared on-campus students with students that lived with parents. They controlled for a large quantity of other variables, and found that Black students who lived on campus were likely to have higher GPAs than Black students who lived at home (López Turley \& Wodtke, 2010). The authors then implored colleges and universities to think about their residence halls in terms of the benefits they have for students of color. They posited that on-campus living provided additional benefits for those students that would have otherwise struggled in college. Although these studies have their flaws and limitations, they ask critical questions about the primary beneficiaries of on-campus housing.

Various well-regarded studies have shown both advantages and challenges for students from underrepresented populations. Researchers that found advantages typically attributed them to the power of residence halls to break down barriers and increase familiarity and comfort with others from different backgrounds. For example, two studies found that African Americans who were assigned rooms with White students experienced a better sense of belonging and received a higher GPA than those who roomed with other African Americans (Shook \& Clay, 2012; Shook $\&$ Fazio, 2008). This research took place at a single predominantly White institution (PWI), and used internal data from the housing department. The researchers theorized that rooming with a 
White student could potentially assist African American students in their transition to a PWI. They speculated that, by witnessing the transition struggles of their White roommates, African Americans may better understand that the transition to college is universally difficult, and not just for African Americans at PWIs (Shook \& Clay, 2012). Such studies make only tangential references to the sense of belonging and involvement advocated in the foundational theories of student development. Davenport (2010), however, tackled this head-on. By surveying students directly, she found that residence halls and other non-academic interactions could offer a greater sense of belonging to Black students and first-generation students than any other demographic. These studies imply that minority students may have more to gain from living in residence halls than majority students.

Other studies, however, have suggested that residence halls offer less to minority students. These studies highlight the deleterious social effects of race. For example, Greyerbiehl and Mitchell (2014) used a survey to find that Black female students at one PWI consistently felt like they had less social capital than their majority peers, and that the same students sought out historically Black sororities for the kind of community that they could not find in the residence halls. Similar findings were reported by Johnson and others, who used a national student survey (Johnson et al., 2007). They found that the climate of the residence hall was highly consequential for Black students at PWIs, and that poor climates often led to a reduced sense of belonging at the institution. Such findings suggest that residence halls can offer negative environments for minority students at the same time they offer positive ones for majority students.

An interesting interaction between residence halls and family income was found by Schudde (2016). Schudde used the ELS data to pull student demographic data and persistence 
numbers. After controlling for differences and running regression models, Schudde found a fascinating interaction; students from high-income and moderate-income families demonstrated higher persistence rates from living in residence halls, but students from low-income families experienced no benefit (2016). The benefit, it seems, was not experienced by the most disadvantaged population. The author speculated that this could be due to the moderating factor of work. Residence halls' benefit, she argued, comes from the interaction with peers and educational programming offered by staff. However, if a low-income student must spend additional hours outside the classroom at work, then they have little time available to enjoy the benefits of on-campus housing. As a result, they do not enjoy the increased retention rates of their well-off peers. Such research has troubling implications for practitioners.

The research theme of disparate impacts is still developing. Although no clear conclusions have been drawn, the literature implies that not all residents enjoy the same benefits from residence hall living. In most cases, it seems that majority students may receive a greater degree of benefits than their minority peers. If true, these results are a disconcerting indictment of the work of residence hall professionals. Practitioners seek to engage and involve all residents, and these studies indicate that more may need to be done to tailor efforts to specific populations. This is area warrants further investigation.

\section{Gaps and Limitations}

As shown in the previous sections, the state of the literature surrounding the benefits of residence halls is detailed, but still has room for growth. Using the taxonomy of Astin (1973), the research was categorized into that which sought to describe the cognitive outcomes, and that which sought to describe affective outcomes. Scholar of the cognitive effects of on-campus living produced solid arguments for why residence halls should have a beneficial influence on 
critical thinking skills, attitudes toward diversity, and academic success, but this has been difficult to prove. Contradictory evidence has plagued this field. Standing in contrast, scholars of the affective influences of on-campus living have found unanimous agreement. Residence hall living has been consistently found to influence social groupings, alcohol use, and student persistence. The theme of disparate impacts is still emerging, but has so far posed some critical questions. Compared to the cognitive and affective themes, the research surrounding disparate impacts appears to be underdeveloped.

The research designs of the examined studies used various methodologies. Quantitative approaches were used almost exclusively. As a result, they are favorable to replication and precise measurements. The statistical methods were varied. A fair amount of studies used correlational methods (such as ANOVA). These approaches, however, only have a tenuous grasp on a claim to causality. They can only claim that two variables are correlated, and cannot assert causality (Pring, 2015, p. 81). For this reason, such studies should be carefully discussed; they cannot claim to prove that a student's place of residence causes any particular outcome. By contrast, regression models are the appropriate for determining the factors that predict certain variables. Claims to prediction are only appropriate with such methods. Among all the examined studies, those that used regression models include the works of Schudde (2011; 2016) and Araujo and Murray (2010). These provide strong examples for research questions that seek predictive models.

As with any social science research, the research presented presents some concerns regarding internal validity. It is difficult to claim that residence halls alone are responsible for the changes seen in students. Students bring their own personal histories with them to campus, which continue to affect them long after they leave home. These experiences could make them 
more or less likely to benefit from living on campus. Further, students are exposed to many experiences and encounters outside of the residence hall. The confounding influence of these engenders questions about the true source of student benefits. In other words, there are innumerable, unpredictable elements that impact the outcomes of students, and it is difficult to attribute significant impact to one interaction or incident (Pring, 2015, p. 144). The best studies are those that control for a variety of personal and environmental factors. In doing so, they remove confounding influences and isolate the variable of on-campus residence. Astin (1993) stresses the importance of doing so when he explained his I-E-O model, noting that high school academic success is the best predictor of college success, and that any collegiate treatment studies should control for it. Literature has also shown that faculty interaction, family income, and student expectations are strong influences which must be taken into account (Mayhew et al., 2016). Among the aforementioned studies, those that best controlled for appropriate external factors include Cross et al. (2009), López Turley and Wodtke (2010), and the works of Schudde (2011; 2016). These steps to control for external variables provide a positive example for future research.

The generalizability, or external validity, of some of these studies is limited. As surveybased quantitative studies, they already provide more external validity than an interview-based qualitative study. However, sample size is an important consideration. A large number of studies examined used single-institution surveys. In this way, only the student body of one campus was taken into consideration. While most methodologies were sound, this still leaves open the possibility that campus-specific factors influenced the results. For example, Pike's (2002) single-institution survey design suggested that living on-campus made students more open to diversity. Left unanswered, however, are whether this dynamic was only present on the 
campus that Pike surveyed, or if such results were expected to be found on others as well. Institutions across the nation have starkly different sizes, compositions, affiliations, and unique traditions. Only studies that include large, multi-institution samples can claim to describe a widespread phenomenon. National federal datasets offer one possible answer to this. Of the examined studies, those that used large samples included Padgett et al. (2012), the works of Schudde (2011; 2016), and DeAngelo (2014). They offer a model for future studies that seek to examine widespread phenomena.

\section{Chapter Summary}

Although the field of student affairs is barely five decades old, it is today firmly embedded in the educational mission of most universities. As colleges and universities have evolved into their current form, so too have campus housing programs evolved. The private boarding house gave way to the students' quarters, which gave way to the paternalistic dormitory, which has become the modern developmental residence hall. The form and function of these halls has followed student development theory and research.

Residence hall programs seek to make manifest the goals of theoreticians. Following Alexander Astin, they seek to involve and engage residents. Following Vincent Tinto, they strive to create welcoming communities in which residents feel a sense of belonging. Taking heed from Arthur Chickering and Nancy Schlossberg, they promote student development and transition to college life. These models show that the college experience can be a formative time for a student, and that students interact with residence halls at a critical juncture. For this reason, residence halls and students' experiences in them are a worthy field of study. A review of these theories has shown that they provide residence life professionals with the tools to meaningfully influence the development of students, even in the context of the current generation. 
A review of the current state of research regarding residence life reveals that it has matured a great deal since its foundations in the 1970s. The field has been well-researched, and several prominent authors have conducted comprehensive meta-analyses. As a result, we have a strong holistic understanding of the effects of on-campus living.

Definitively, we can state that living in a residence hall is a formative experience for an undergraduate student. It has a significant influence on the affective behavior of the student. Residential students are more likely to form friendships, get involved on campus, and interact with faculty and staff. Their patterns of alcohol use and abuse are also likely to be affected. In addition, living in a residence hall makes a student more likely to persist in their second year and complete their college degree. Cognitive effects of on-campus living are more difficult to pin down. The literature is mixed regarding the effects on critical thinking and academic achievement; some claim that it helps, while others have been unable to confirm these findings. Similarly, there are inconclusive findings for the role of residence halls in students' feelings toward diversity and reduction of prejudice. Satisfaction and sense of belonging, however, have been found to be an area of cognitive effects that are clearly and consistently improved by living in university housing.

To what degree these benefits are enjoyed by diverse populations is unclear. How nonmajority populations benefit in comparison to majority populations is a field that has only recently been explored. Separate studies have shown both increased and reduced magnitudes of benefits for various populations. These studies have examined both cognitive and affective effects. Strong methodologies have been developed, but comprehensive studies have yet to be conducted. 
For this reason, the disparate impact of living on-campus is the most consequential unresolved issue in the field of residence hall research. Who benefits and who does not is an important issue for residence hall professionals. This would have weighty implications for practice, as it would guide professionals on who may need more assistance in, say, developing a sense of belonging on the campus. Unresolved questions of note include: Do minority students enjoy the same boost in persistence as White students? Do students of all sexual identities experience the same sense of satisfaction with their residence hall environments? Do students of various demographic backgrounds experience the same sense of belonging? Resolving these questions can help to identify ways that residence hall staff can target or tailor their services in the most impactful ways. This study seeks to answer the first question. 


\section{CHAPTER III: METHOD}

\section{Overview}

The goal of this study is to compare the influence of residence hall living on student persistence between White and nonwhite students at predominantly White institutions.

This study answers the following research questions:

1. Is living in a residence hall a significant determinant of sophomore year persistence at PWIs for students of all races?

2. How do the probabilities for persistence compare for students based on race?

\section{Research Design}

This study employs a longitudinal research design using archival data. Given the nature and import of students' college careers, an experimental design is neither feasible nor advisable. To accurately track the actions of students, a design that measures students over time is necessary to identify the necessary variables. A mass longitudinal study is preferable over a cross-sectional design because it surveys more individuals and is capable of conveying a more complete narrative.

This study uses a logistic regression analysis to identify predictors on a binary dependent variable (persistence/dropout). This regression will distinguish the predictive value of choice of residence and selected covariates, and will compare these odds by student race/ethnicity.

\section{Population and Sampling Procedures}

This study uses data from the Beginning Postsecondary Students (BPS) longitudinal study. The BPS, in large part, draws its data from the National Postsecondary Student Aid Study (NPSAS), a study by the National Center for Education Statistics. NPSAS is a nationwide student survey that followed cohorts of students and followed up with interviews at regular 
intervals. Its design includes the sampling strategies necessary to be a nationally representative sample. Although the goal of NPSAS is to examine the ways in which undergraduate students pay for college, it is a rich dataset that collects a great deal of information. As a result, the BPS is one of two "spin-off" studies that use specific data from NPSAS. Additional data points not available in the NPSAS were also folded into the BPS data.

The most recent cohort of BPS students began their postsecondary careers in 2012. They were followed over time, with follow-up interviews conducted in 2014 and 2017. Each round of follow-ups added more data points to the student case. The 2014 data is all that is needed for this study; a given student's persistence into their second year of college would have been determined in 2013.

Sampling was done by identifying qualifying participating institutions, and then by narrowing the student pool to those that were degree-seeking and were entering college for the first time. Students were chosen based on geographic location and other demographics to be nationally representative. This resulted in over 30,000 student records for the dataset.

\section{Instrumentation and Measures}

As mentioned above, data on institutional profiles and financial aid packages were pulled directly from government databases. This was done with the consent of the cooperating institutions.

Student interviews were conducted via phone or web survey, and contained elements that had been present in previous iterations of the BPS study (prior cohorts include those students who began college in 1990, 1996, and 2004). Students were asked to self-disclose information on a variety of topics, including high school preparation, college and career expectations, major 
choice, earnings expectations, and physical and mental health. Additional information was cross-referenced with students' FAFSA applications and financial aid documentation.

As follow-up interviews were conducted, the students' answers about their enrollment status allowed them to be sorted into groups. These groups included "leavers" and "persisters." All students remained in the survey, regardless of enrollment status. Tailored questions were given to individuals based on this grouping. Teams of dedicated researchers toiled to reach high response rates, ensuring the representativeness of the sample size and thus the reliability of the data. Both the survey instruments and the compiled dataset represent the "gold standard" of college student research, and both the BPS dataset and the NPSAS from which it is derived have been the premier choice of researchers and public policy analysts for over 25 years.

\section{Data Source and Procedures}

The BPS dataset is compiled from multiple sources. Students are surveyed and interviewed, providing data regarding their home environment, family background, previous experiences, and their expectations about college. In addition, the National Center for Education Statistics pulls additional financial information, such as financial aid, along with demographic data about the institutions they attend, from existing government databases. As a result, the BPS is a comprehensive dataset that is used for a variety of research purposes and public policy decisions.

As mentioned earlier, the BPS federal dataset is sufficiently robust for the purposes of this study. The variables that will be used by this study include:

- Dependent variables

○ Sophomore year persistence (categorical)

- Independent variables

- Place of residence (categorical)

- Student race (categorical)

- Institution type (categorical) 
- Confounding variables to be controlled for

- Family income (continuous, but can be made categorical)

- High school GPA (continuous, but can be made categorical)

- Student expectations (categorical)

○ Student work hours (continuous, but can be made categorical)

All of these are found within the 1,300 variables available in the BPS dataset. Additional data collection is unnecessary. In addition, NCES staff already screened the data for incompleteness prior to making it available to the public.

\section{Data Analysis Procedures}

A logistic regression analysis was used to answer the research questions. The primary variables, both dependent and independent, are categorical. In addition, the research questions are focused on the question of probability and prediction. As a result, the most appropriate statistical method is logistic regression.

A logistic regression analysis is appropriate for this study. Student persistence is a "yes or no" question; the student either persists, or leaves the college or university. For this reason, a logistic regression is more appropriate than a factorial analysis of covariance (ANCOVA), which requires a continuous or quantitative dependent variable. In addition, a logistic regression permits multiple dependent variables of various types. Furthermore, this study seeks to identify the predictive ability of the independent variables. This is exactly the type of question that a logistic regression can answer.

Given the plethora of independent and confounding of variables, there are many influencing factors on the dependent variable. Logistic regression, unfortunately, does not directly control for the influence of confounding variables. Such a step is typically the domain of ANCOVA or MANCOVA studies. However, as mentioned above, these analysis tools are inappropriate for this study. This does not, however, leave this study without options for 
considering the influence of confounding variables. By using stepwise criteria in the logistic regression, this study can examine the influence of all variables. Although this will not "control for" these variables in a traditional sense, it will permit the reader to examine their comparative influence. As known influencers, one can then compensate for their influence. A stepwise table will allow the study to view the independent variables' influence after that of the confounding variables.

A logistic regression analysis has no assumptions about the independent variables. The independent variables did not need to be prescreened for normal distribution, skew, or linearity. As a result, no "fixing" of the data was required before analysis could begin. The only consideration is collinearity of the independent variables. However, this is no concern; it is highly unlikely that there is a collinear relationship between student ethnicity and their place of residence.

Descriptive statistics are important to consider for this study. Distributions of the key variables, including the mean, median, and mode, are essential to examine. Although the National Center for Education Statistics assures users that the data set is nationally representative, this should be statistically confirmed. Frequency tables assess if all relevant populations and subpopulations were adequately represented.

This study sought and received the Beginning Postsecondary Students longitudinal study data from the National Center for Education Statistics. As a stipulation of receiving and handling this data, strict procedures were to be followed. All restricted-use data is subject to these national security measures. All data was kept with the strictest confidentiality. The data was kept on a non-networked desktop computer only. The data was not "backed up" in any other location, nor transported outside of the research office. Only the study author had access to 
analyze the data. Collaboration with the Graduate School at Illinois State University and the Institutional Review Board was critical for acquiring the appropriate licensure.

\section{Internal and External Validity}

This study's design offers extensive protections of internal and external validity. Internal validity is a reference to a study's ability to assign effects to manipulation of one or more independent variables. A study that lacks internal validity does not control confounding variables, or fails to take other influences into account. This study protects internal validity by controlling for a host of variables that are known to influence student retention. A review of the literature reveals the strong and well-documented effect held by a student's high school GPA, family income, expectations of college life, and the degree to which the student works while attending college. A long series of studies have shown these to be meaningful factors in student retention. Luckily, data on each of these is collected as a part of the NPSAS and BPS dataset. Consequently, they were available to use in this study. These variables were included in the logistic regression analysis. By including their effects as a part of the study, one can isolate those of the study variables. This will preserve internal validity.

External validity can also be assured. External validity is a reference to a study's ability to generalize findings to the general population. In other words, it gauges whether or not a study's findings can apply only to the population that is studied, or also to others in the future. Thanks to the robust data provided by NPSAS, this study can make that claim. The data was collected in a natural setting, with minimal researcher presence. In addition, the National Center for Education Statistics intentionally tailored the sample population so that it represented an accurate cross-section of college attendees. This sampling accounted for student demographics, 
institutional profiles, and geographic location. As a result, one can rest easy knowing that this study used the most comprehensive and representative dataset available to researchers.

\section{Chapter Summary}

The purpose of this chapter was to present the research questions for this study, along with the data source, a discussion of its merits, and the statistical analyses. With these, this researcher aims to fulfill the purpose of this study, which is to compare the influence of residence hall living on student persistence between White students and students of color at predominantly White institutions. 


\section{CHAPTER IV: RESULTS}

\section{Coding}

The BPS dataset is a rich source of information. The entire sample offers nearly 30,000 student cases. With the 2012 initial data and the 2014 follow-up information, there are just over 1,300 variables in the set. When reporting frequencies, values are rounded to the nearest 10 in compliance with NCES confidentiality and statistical standards.

Some recoding was required in order to prepare the dataset for analysis. In the original dataset, the variable "PROUTF2", which represented cumulative persistence and attainment anywhere for the 2012-2013 academic year, was recoded from a categorical variable into a dichotomous variable. Values 1 through 3, which represented students who had completed a bachelor's degree, associate's degree, or professional certificate, were omitted. This resulted in the loss of 360 cases. Values 4 and 5, which represented students who were still enrolled in some capacity, were recoded into Value 1 in the new variable "ZZPERSTRUEINV." Values 6 and 7, which represented students who ceased their educational pursuits without achieving a degree, were recoded in Value 0 in the new variable. This allowed for a dichotomous "Yes/No" variable that represented student persistence.

Similarly, local residence was recoded into a dichotomous variable. In the original dataset, the variable "LOCALRES" represented the type of housing that students lived in for the 2011-2012 academic year (their first year of higher education). The original values $(1=$ on campus, $2=$ off campus, $3=$ living with parents, and $4=$ attending more than one institution) were recategorized logically into a new variable "ZZLOCALRESINV" where the value 1 represents students living on campus, and the value 0 represents all others. 
Finally, two variables were recoded from continuous variables into ordinal variables at specific intervals. The original dataset featured variables for family income in the 2011-2012 academic year ("CAGI"), and average weekly hours worked by the student in the 2011-2012 year ("HRSWK12"). As continuous variables, these would not be useful for the analysis; one can safely assume that one additional dollar in family income would provide little benefit for a student, much in the same way that one additional hour would have little harm. Using the FREQUENCIES function in SPSS, quintiles and quartiles were determined for these variables. These sections were used to create categories that were roughly equal in population size. The new ordinal variable for family income, "ZZGAGICAT," had 5 values $(1=\$ 0$ to $\$ 12,000$ per year, $2=\$ 12,001$ to $\$ 30,000$ per year, $3=\$ 30,001$ to $\$ 60,000$ per year, $4=\$ 60,001$ to $\$ 100,000$ per year, and $5=$ over $\$ 100,001$ per year). The new ordinal variable for average weekly hours worked, "ZZHRSWK12CAT," had 4 values $(1=$ no hours worked, $2=1$ to 19 hours worked, $3=$ 20 to 39 hours worked, and $4=40$ or more hours worked).

Of the variables of interest for this study, only two required no modification. The variable "HSGPA" featured students' self-reported high school cumulative grade point average. It featured 7 values corresponding to value ranges $(1=0.5-0.9$ [D- to $D$ ], $2=1.0-1.4$ [D to $C-$ ], 3 $=1.5-1.9[\mathrm{C}-$ to $\mathrm{C}], 4=2.0-2.4[\mathrm{C}$ to $\mathrm{B}-], 5=2.5-2.9[\mathrm{~B}-$ to $\mathrm{B}], 6=3.0-3.4[\mathrm{~B}$ to $\mathrm{A}-\mathrm{]}$, and $7=3.4$ to 4.0 [A- to A]). Another variable, "PRECONF," was a measure of students' self-reported educational confidence. Students were asked, "Before I attended my first institution, I was confident I had the ability to succeed there as a student." Their responses were coded to separate value labels $(1=$ Strongly disagree, $2=$ Somewhat disagree, $3=$ Neither disagree nor agree, $4=$ Somewhat agree, $5=$ Strongly agree) . 
The dataset included a great diversity of students attending many types of institutions. To filter out data from extraneous cases, the SELECT CASES function of SPSS was used in conjunction with several available variables. The variable "FLEVEL" was used to filter out any cases with a value other than " 1 ," which removed all but students attending 4-year institutions. The variable "HBCU" was used to filter out any cases with a value other than " 0 ," which removed historically Black colleges and universities. The variable "DELAYENR" was used to filter out any cases with a value other than " 0 ," which removed any student that delayed their college enrollment following high school, leaving only traditional-aged college students. With these filtering steps taken, 9,190 cases remained.

To identify and eliminate multivariate outliers, this study employed the calculation of the Mahalanobis distance. This number measures the number of standard deviations from the case mean for each case. To do this, the REGRESSION > LINEAR function in SPSS was used, and Mahalanobis distances were saved under the new variable "MAH_1." The chi square table was then consulted to determine the appropriate level of exclusion. For $d f=4$ and $\alpha=.01$, the critical value is 13.2767. With this information, the SELECT CASES function is SPSS was once again used to filter out any cases where the "MAH_1" variable was greater than or equal to 13.2767. This step filtered out 130 cases, or $1.4 \%$ of the 9,190 cases that met the study criteria. This left 9,060 cases to analyze.

\section{Description of Sample}

9,060 cases were selected from the expansive BPS data set. These represent all surveyed cases of students, nationwide, who enrolled in a predominantly White 4-year institution of higher education for the 2011-2012 school year, immediately following their high school graduation. This is the largest such sample size available to researchers. 
The filtered student cases provided a diverse population with which to conduct the analysis. Table 1 below illustrates the demographics of the sample.

Table 1 Demographic Frequencies of Sample

\begin{tabular}{lrrr} 
Race Category & Frequency & Percent & Cumulative Percent \\
\hline White & 5370 & 59.3 & 59.3 \\
Black or African American & 1030 & 11.3 & 70.6 \\
Hispanic or Latino & 1570 & 17.3 & 87.9 \\
Asian & 560 & 6.1 & 94.1 \\
American Indian or Alaska Native & 50 & .6 & 94.6 \\
Native Hawaiian / Other Pacific Islander & 30 & .4 & 95.0 \\
More than one race & 380 & 4.1 & 99.2 \\
Foreign students & 70 & .8 & 100.00 \\
\hline Total & 9060 & 100.00 & \\
\hline
\end{tabular}

SOURCE: U.S. Department of Education, National center for Education Statistics, 2012/14 Beginning Postsecondary Students Longitudinal Study.

Within this sample, three categories provide cause for concern. Three of the self-reported race categories ("American Indian or Alaska Native," "Native Hawaiian / Other Pacific Islander," and "Foreign students") have very low sample sizes. Each represents less than $1 \%$ of the full sample. Not every race category had a minimum of 10 cases for each of the predictor variables. As a result, results for these categories should be interpreted with great caution. They are presented nevertheless in order to draw distinction where possible. 
This sample of students provided a strong sampling of the other variables of this study.

Self-reported high school grade point averages were distributed normally, with the mode in the high B to low A range (as would be anticipated for college-bound high school graduates). The frequencies are shown in Table 2 below.

Table 2 GPA Frequencies of Sample

\begin{tabular}{lrrr}
\hline High School GPA & Frequency & Percent & Cumulative Percent \\
\hline $0.5-0.9$ (D- to D) & 10 & .0 & .9 \\
$1.0-1.4$ (D to C-) & 80 & .9 & 3.0 \\
$1.5-1.9$ (C- to C) & 190 & 2.1 & 15.5 \\
$2.0-2.4$ (C to B-) & 1130 & 12.5 & 28.2 \\
$2.5-2.9$ (B- to B) & 1150 & 12.7 & 68.6 \\
$3.0-3.4$ (B to A-) & 3660 & 40.4 & 99.2 \\
$3.5-4.0$ (A- to A) & 2770 & 30.6 & 100.00 \\
Skipped & 70 & .8 & \\
\hline Total & 9060 & 100.00 & \\
\hline
\end{tabular}

SOURCE: U.S. Department of Education, National center for Education Statistics, 2012/14 Beginning Postsecondary Students Longitudinal Study.

The other variables have large sample sizes. The dichotomous variables of student residence (living on campus or living off campus) and persistence (leavers or persisters) are presented in with frequencies in Table 3 and Table 4 below.

Table 3

Residence Frequencies of Sample

\begin{tabular}{lrrr}
\hline Residence Location & Frequency & Percent & Cumulative Percent \\
\hline Off Campus & 3910 & 43.1 & 43.1 \\
On Campus & 5150 & 56.9 & 100.00 \\
\hline Total & 9060 & 100.00 &
\end{tabular}

SOURCE: U.S. Department of Education, National center for Education Statistics, 2012/14 Beginning Postsecondary Students Longitudinal Study. 
Table 4

Persistence Frequencies of Sample

\begin{tabular}{lrrr}
\hline Persistence & Frequency & Percent & Cumulative Percent \\
\hline Left College & 1140 & 12.6 & 12.6 \\
Persisted & 7920 & 87.4 & 100.00 \\
\hline Total & 9060 & 100.00 & \\
\hline
\end{tabular}

SOURCE: U.S. Department of Education, National center for Education Statistics, 2012/14 Beginning Postsecondary Students Longitudinal Study.

\section{Findings}

A logistic regression was run using the REGRESSION > BINARY LOGISTIC function in SPSS. The dependent variable of "ZZPERSTRUEINV" was selected, and independent variables "ZZLOCALRESINV," "HSGPA," "ZZCAGICAT," “ZZHRSWK12CAT,” and "PRECONF" were selected. The variable "RACE2" was used as a selector variable, and the logistic regression was run once for each of the eight self-reported race/ethnicity categories $(1=$ White, $2=$ Black or African American, $3=$ Hispanic or Latino, $4=$ Asian, $5=$ American Indian or Alaskan Native, $6=$ Native Hawaiian or other Pacific Islander, $7=$ More than one race, and 8 $=$ Foreign students). These categories were based off of options presented in the U.S. Census and were self-selected by study participants. Each binary logistic regression was run with stepwise analysis in order to determine the effect size of each variable. Although binary logistic regression does not provide an ability to "control for" the influence of particular variables, a stepwise presentation of the results can illustrate the comparative weight of each variable, and the increase or decrease when each variable is considered. Such a presentation is offered below.

The stepwise logistic regression for White students $(n=5,370)$ yielded a model that included student residence, high school grade point average, family income, and hours worked. Academic confidence failed to produce results at a significance threshold less than .1, and as a result it was automatically removed from the model. The final model produced a chi-square 
value of 426.262 at $p<.001$. The Nagelkerke $R^{2}$ was .163 , indicating that the model accounted for $16.3 \%$ of the variance. $90 \%$ of cases were correctly predicted using the model. When including all significant variables, the odds ratio $\operatorname{Exp}(B)$ for residence was 3.022 at $p<.001$, which indicates that living in a residence hall made a White student 3.022 times more likely to persist into their second year of college than those White students who lived off-campus.

Identical stepwise logistic regression analyses were performed for each of the remaining self-reported ethnicity groups. For Black or African American students $(\mathrm{n}=1,030)$, academic confidence was not included in the model due to insignificance. The final model produced a chisquare value of 102.185 at $p<.001$. The Nagelkerke $R^{2}$ was .144 , indicating that the model accounted for $14.4 \%$ of the variance. $75.9 \%$ of cases were correctly predicted using the model. When including all significant variables, the odds ratio $\operatorname{Exp}(B)$ for residence was 2.371 at $p<$ .001 , which indicates that living in a residence hall made a Black student 2.371 times more likely to persist into their second year of college than those Black students who lived off-campus.

For Latino students $(n=1,570)$, academic confidence was not included in the model due to insignificance. The final model produced a chi-square value of 121.083 at $p<.001$. The Nagelkerke $R^{2}$ was .127 , indicating that the model accounted for $12.7 \%$ of the variance. $84 \%$ of cases were correctly predicted using the model. When including all significant variables, the odds ratio $\operatorname{Exp}(B)$ for residence was 2.244 at $p<.001$, which indicates that living in a residence hall made a Latino student 2.244 times more likely to persist into their second year of college than those Latino students who lived off-campus.

For Asian students $(\mathrm{n}=560)$, only residence and family income provided significant results for the model. The final model produced a chi-square value of 17.775 at $p<.001$. The Nagelkerke $R^{2}$ was .080 , indicating that the model accounted for $8 \%$ of the variance. $93.1 \%$ of 
cases were correctly predicted using the model. When including all significant variables, the odds ratio $\operatorname{Exp}(B)$ for residence was 3.005 at $p=.004$, which indicates that living in a residence hall made an Asian student 3.005 times more likely to persist into their second year of college than those Asian students who lived off-campus.

Three groups ("American Indian or Alaska Native," "Native Hawaiian / Other Pacific Islander," and "Foreign students") had low sample sizes that yielded aberrant results. Residence did not produce significant results for any of these three groups, and was not included in their models.

The results for students that reported themselves as "More than one race" $(n=380)$ was likewise noticeably divergent from the others. The final model produced a chi-square value of 26.439 at $p<.001$, yet included only the variables of family income and academic confidence (which had been excluded in all other regressions). The Nagelkerke $R^{2}$ was .123 , indicating that the model accounted for $12.3 \%$ of the variance. $86.3 \%$ of cases were correctly predicted using the model. The odds ratio $\operatorname{Exp}(B)$ for family income was 1.393 at $p=.003$, while that of the academic confidence variable was 1.795 at $p<.001$. A presentation of all results can be found in Table 5 below. 
Table 5

Logistic Regression

95\% Confidence

Interval for Odds Ratio

\begin{tabular}{|c|c|c|c|c|c|c|c|c|}
\hline Race Category & $\begin{array}{l}\text { Overall \% } \\
\text { Correct }\end{array}$ & B & Wald & df & $\mathrm{p}$ & $\begin{array}{l}\text { Odds } \\
\text { Ratio }\end{array}$ & Lower & Upper \\
\hline White & $90.0 \%$ & & & & & & & \\
\hline Residence & & 1.106 & 115.730 & 1 & .000 & 3.022 & 2.500 & 3.701 \\
\hline GPA & & .370 & 81.486 & 1 & .000 & 1.447 & 1.241 & 1.475 \\
\hline Income & & .344 & 91.734 & 1 & .000 & 1.410 & 1.345 & 1.543 \\
\hline Hours Worked & & .342 & 30.970 & 1 & .000 & 1.407 & 1.261 & 1.528 \\
\hline $\begin{array}{l}\text { Black or African } \\
\text { American }\end{array}$ & $75.9 \%$ & & & & & & & \\
\hline Residence & & .863 & 27.871 & 1 & .000 & 2.371 & 1.721 & 3.267 \\
\hline GPA & & .246 & 15.706 & 1 & .000 & 1.279 & 1.132 & 1.444 \\
\hline Income & & .302 & 20.856 & 1 & .000 & 1.353 & 1.188 & 1.540 \\
\hline Hours Worked & & .433 & 18.073 & 1 & .000 & 1.542 & 1.263 & 1.882 \\
\hline Hispanic or Latino & $84.0 \%$ & & & & & & & \\
\hline Residence & & .808 & 21.585 & 1 & .000 & 2.244 & 1.596 & 3.157 \\
\hline GPA & & .358 & 37.689 & 1 & .000 & 1.431 & 1.276 & 1.605 \\
\hline Income & & .192 & 10.069 & 1 & .002 & 1.211 & 1.076 & 1.363 \\
\hline Hours Worked & & .447 & 22.620 & 1 & .000 & 1.564 & 1.301 & 1.880 \\
\hline Asian & $93.1 \%$ & & & & & & & \\
\hline Residence & & 1.100 & 8.075 & 1 & .004 & 3.005 & 1.407 & 6.419 \\
\hline $\mathrm{GPA} \dagger$ & & - & - & - & - & - & - & - \\
\hline Income & & .285 & 4.512 & 1 & .034 & 1.329 & 1.022 & 1.729 \\
\hline
\end{tabular}

American Indian or $\quad 76.9 \%$

Alaskan Native

Residence $\dagger$

GPA

Income $\dagger$

Confidence

$\begin{array}{rrrr}- & - & - & -\end{array}$

2.248

1.119

4.516

.938

$3.731 \quad 1 \quad .053$

2.556

6.623

Native Hawaiian or $\quad 87.9 \%$

Pacific Islander

Residence $\dagger$

GPA

Income $\dagger$

More than one race $\quad 86.3 \%$

Residence $\uparrow$

GPA $\dagger$

Income

Confidence

$\begin{array}{llll}.332 & 8.886 & 1 & .003\end{array}$

1.393

1.120

1.733

$\begin{array}{llll}.585 & 17.954 & 1 & .000\end{array}$

1.795

1.370

2.353

$\dagger$ Variable not included in model

SOURCE: U.S. Department of Education, National center for Education Statistics, 2012/14

Beginning Postsecondary Students Longitudinal Study. 


\section{CHAPTER V: DISCUSSION}

\section{Introduction}

This study aimed to determine if nonwhite students enjoy the same boost in persistence as White students from their on-campus residence. To do that, data from the Beginning Postsecondary Students study was analyzed to compare the influence of residence hall living on student persistence between White and nonwhite students at predominantly White institutions. The analysis produced several statistically significant results.

First, some discussion is due to the degree with which these models predict variance in the dependent variable (sophomore year persistence). Although a logistic regression analysis does not produce a traditional R-square value, SPSS offers an approximation. The "Nagelkerke $R^{2}$ " value presented attempts to offer such a value. It is a "pseudo- $\mathrm{R}^{2 "}$ in that it is a linear representation of a logistic curve. As a result, it should be interpreted carefully.

Each model of logistic regression produced relatively low Nagelkerke $R^{2}$ values. They ranged from $16.3 \%$ for White students to $8 \%$ for Asian students. This would imply that the model is of little use. However, when these numbers are considered in the context of the other findings (clear significance values, high rate of correct prediction, noticeable odds ratios), these results should still be considered consequential. A variety of factors are at play in a student's tumultuous first year of higher education. Innumerable factors, many of which cannot be quantified, shape the relative positivity or negativity of their experience. It is a time of transition, and often daunting, even in the best of times. Academic readiness and personal financial factors unquestionably have a major influence on a student's ability to remain enrolled. That this model, of which residence is a part, can predict even one-tenth of the variance in student persistence is noteworthy. Colleges and universities would be thrilled to predict $10 \%$ of 
the students that are likely to drop out before their second year; they would undoubtedly use such information to target those students with intense retention efforts.

Second, it is worth noting that the variable of residence produced the highest odds ratios of any variable for any group. This further corroborates the overwhelming consensus in the literature that living in an on-campus residence hall is a significant predictor of persistence. The analysis shows that, as the variable changes from 0 to 1 (from living off-campus to living oncampus), the chances of persisting for a second year are positively affected. Interestingly, the odds ratios appear to draw an interesting comparison to the influence of high school GPA and family income. When comparing the odds ratios for these values among White, Black, and Latino students, it appears that residence has as much of or more of a predictive ability than an increase of a full letter grade, or having a family income that is two quartiles higher.

\section{Research Questions}

This study sought to answer the following research questions:

1. Is living in a residence hall a significant determinant of sophomore year persistence at PWIs for students of all races?

2. How do the probabilities for persistence compare for students based on race?

This study was unable to fully answer the first question for all self-reported race groups. The sample size of students that identify as American Indian or Alaska Native, Native Hawaiian / Other Pacific Islander, or Foreign students was comparatively small and produced unreliable data when submitted for analysis. Students that identify as "More than one race" presented a somewhat larger sample size, yet the model did not include residence as a significant predictor. As a result, this question cannot be answered for these groups. 
Residence did, however, prove to be a clear determinant of sophomore year persistence for White, Black, Latino, and Asian students. Together, these 4 groups comprised $94.1 \%$ of the sample population. For these groups, living in a residence hall predicted a considerable increase in the likelihood to persist into the second year. Other variables that had a known influence on student success were included in the stepwise regression, which allowed this study to "control for" their influence, even in the absence of a traditional statistical way to do so. With these included, the residence variable was effectively isolated, allowing this study to view its influence separately.

With that in mind, this study indicates that the answer to Research Question 1 is "yes" for the four largest ethnic groups.

The second research question is easily deduced by comparing the odds ratios of the residence variable at the final step of each logistic regression model. For White students, this was 3.022. For Black or African American students, this was 2.371. For Hispanic or Latino students, this was 2.244. For Asian students, this was 3.005. These numbers represent the comparative increase in likelihood to persist as a result of living on campus; White students were 3.022 times more likely to persist, Black students 2.371 times as likely, and so on. While oncampus residence is clearly a boon to persistence for all groups, they do not share it equally. There is a disparate benefit.

Although other studies have hinted at this outcome, most used geographically-bound data, allowing the possibility that their results were local and not national. This study, by using a national dataset, indicates that the disparate benefit is a nationwide phenomenon.

It is not possible that the disparity in persistence odds is the result of other variables not included in this study. As mentioned earlier, the college experience is rife with challenges and 
opportunities. There are no doubt other factors that influence student persistence. However, the nature of the logistic regression methodology leaves little room for error; this statistical method examines independent variables as predictors of the dependent variable. It would not be possible for a separate variable to cause the fluctuation in the residence variable's odds ratio.

Consequently, one can rely on the numbers presented to accurately reflect the influence of residence location.

\section{Discussion}

Seeing this disparity, one naturally desires to ask why this is. Unfortunately, quantitative studies cannot answer such questions. However, a recap of the literature in this area provides some potential causes.

Schudde (2016) argued that the causal mechanism behind the benefit of residence halls was the time spent engaging with peers in social settings. Not all students, however, are readily welcomed or feel included in majority-population social circles. If a sense of belonging is the crux, then an absence of belonging would result in an absence of benefits, regardless of proximity to peers. Schudde rationalized that students who feel a cultural incongruence or social disconnect would see null effects of living on campus. Even though Schudde's research was focused on low-income students, the same logic may apply for nonwhite students. Racial tension, present throughout society, is present in residence halls as well, and may inhibit nonwhite students' sense of belonging, and consequently their disposition toward persisting in college.

A similar yet slightly different explanation can be found from Johnson et al. (2007). They posit that the social climate of the residence hall is the tipping point for a nonwhite student's transition to college. The perception of this climate as inclusive or exclusive directly 
correlates to the student's sense of belonging at that institution. Such a view allows for positive or negative outcomes from living in a residence hall. According to Johnson, a Black student living in a residence hall named after a slave-owning historical figure would have a tougher time acclimating to college than one whose hall staff had clearly articulated a vision of an inclusive, supportive racial climate. This is not much of a stretch to fathom. It does, however, leave the door open for equity; under the best conditions, Johnson et al.'s model would predict identical benefits realized by students of all racial groups.

Third and finally, Shook and Clay (2012) consider the role of interracial roommate pairings on belonging and academic performance. They argue that minority students who room with majority students at a PWI experience a greater sense of belonging than minority students who roomed with minority students. They suspect that the presence of a majority roommate would widen the social circle of minority students at PWIs, increasing their connection to the institution. They also argue that this boosts academic confidence for the nonwhite student. Conversely, they also argue that minority students who room with minority students are hindered in their ability to connect with others at PWIs, and consequently have a lowered sense of belonging. Shook and Clay argue that, for such students, "there is likely to be a reduced opportunity to disconfirm beliefs that common hardships are attributable to minority group status. That is, minority roommate relationships may provide less opportunity to discourage race-based attributions and expectations of discrimination" (2012, p. 1172). In other words, these students would lack confidence and be more likely to hold self-generated feelings of inadequacy. Such a theory would predict lowered overall rates of persistence for minority students as a result of the averaged-out sense of belonging across minority students at PWIs nationwide (accounting for all roommate pairings). 
These authors would disagree about what the results of this study mean. Schudde would argue that the Black and Latino/a students' lower odds ratio for persistence indicates that race relations are a source of tension on college campuses, and give nonwhite students at PWIs a sense of unease. Johnson and colleagues would likely note that Black students receive a substantial increase in odds to persist by living in a residence hall, and while those odds are not as great as White students (3.022 for White, 2.371 for Black/African American, 2.244 for Hispanic/Latino, 3.005 for Asian), they are still clearly positive. That they do not match those of White and Asian students would, in their estimation, likely be due to deficiencies at select institutions to foster welcoming environments for all populations. Shook and Clay (2012) may point to the lowered odds ratios for Black/African American and Hispanic/Latino populations and see an indicator that these students did not adequately acclimate to the PWI environment. These authors would likely contend that, if only all of these students had integrated more with their White colleagues, they could have fully realized the benefits of the residence hall environment.

On consideration of the preceding interpretations, I would argue that the positions of Schudde and Johnson et al. are far more compelling than that of Shook and Clay. It is wellestablished that Black students have experiences at PWIs that differ greatly from their White peers (Benton, 2001; Araujo \& Murray, 2010). These experiences can be both positive and negative; college campuses are often places where stereotypes are broken down and intergroup relationships are built, but they can also be places of social conflict. In this way, college campuses are microcosms of society as a whole. Administrators, of course, try to create an idealized image of campuses as venues for enlightened discourse and intercultural learning. Yet despite sometimes receiving criticism as "bubbles," colleges and universities are not fully 
insulated from the national social environment. Campuses are also subject to the same social, economic, and racial turbulence that permeates the general public (Blimling, 2015). As a result, Schudde's proposition that PWIs are tinged with enough racial distrust to influence the success of Black and Latino students is plausible.

In addition, the position of Shook and Clay is not borne out by the findings of other studies. They hold that Black students fare better when paired with White roommates, reasoning that this allows them to witness White students struggling in college, thus negating any feelings of racial self-doubt. However, the landmark How College Affects Students includes information that undercuts this thesis. In an extensive meta-analysis of the comparative benefits of PWIs and HBCUs, the authors conclude that "the weight of the evidence suggests that students who enroll at minority-serving institutions perceive greater gains than their peers at PWIs" (Mayhew et al., 2016, p. 40). It seems unlikely that both can be true. If Black students need a White roommate in order to be liberated from self-doubt, how could HBCUs be serving them so well? I argue that Shook and Fazio's claim is unconvincing and refuted by the analysis of other authors. Racially heterogeneous roommate pairings seem unlikely to be the key for Black student success when their success is easily demonstrated in a more homogenous environment. Consequently, I reject their position as an interpretation of this study's findings.

The most likely explanation is an imperfect alignment in the causal mechanism of residence halls' benefits. The conceptual framework of this study, found in Figure 1 on page 3, illustrates this process. Living in a residence hall allows for positive interactions that they would not otherwise have, including increased peer interaction, more direct institutional support, and a heightened sense of belonging. It is these benefits that result in increased persistence odds. The findings of this study suggest that, for Black and Latino students at PWIs, residence halls do not 
provide the same quality of social interaction and belonging, resulting in reduced persistence rate increases.

The difference in odds ratios is meaningful. Living in a residence hall increases every group's odds of persisting, so one naturally wonders if the disparate impact is big enough to be consequential. The 2.371 odds ratio for Black/African American students does not appear to be much different than the 3.022 odds ratio for White students. However, the students who experience the lowered odds ratio are the precise groups who need the boost to persistence rates. In the data set used, a frequency table of drop-outs and persisters by race category and residence location reveals that White students already enjoy a high second-year retention rate at PWIs. Whether living on campus or off, Black and Latino students had higher rates of drop-outs. See Table 6 below.

Table 6

Frequency of Persistence by Race and Residence

\begin{tabular}{|c|c|c|c|c|}
\hline & \multicolumn{2}{|c|}{ Live on-campus } & \multicolumn{2}{|c|}{ Live off-campus } \\
\hline & Drop Out & Persist & Drop Out & Persist \\
\hline \multirow[t]{2}{*}{ White } & 140 & 3190 & 270 & 1490 \\
\hline & $4.1 \%$ & $95.9 \%$ & $15.1 \%$ & $84.9 \%$ \\
\hline \multirow[t]{2}{*}{$\begin{array}{l}\text { Black/African } \\
\text { American }\end{array}$} & 50 & 390 & 140 & 320 \\
\hline & $11.1 \%$ & $88.9 \%$ & $29.5 \%$ & $70.5 \%$ \\
\hline \multirow[t]{2}{*}{$\begin{array}{l}\text { Hispanic/ } \\
\text { Latino }\end{array}$} & 40 & 520 & 170 & 720 \\
\hline & $6.8 \%$ & $93.2 \%$ & $18.9 \%$ & $81.1 \%$ \\
\hline \multirow[t]{2}{*}{ Asian } & 10 & 290 & 30 & 230 \\
\hline & $3.1 \%$ & $96.9 \%$ & $10.2 \%$ & $89.8 \%$ \\
\hline
\end{tabular}

SOURCE: U.S. Department of Education, National center for Education Statistics, 2012/14 Beginning Postsecondary Students Longitudinal Study. 
Residence halls provide a university's best chance to provide students with a sense of belonging. This belonging is the best chance for a student to persist into their second year. From the table above, it is clear this benefit is not being visited equally upon all students at PWIs. The findings of this study reveal that residence halls are not accomplishing as much for Black and Latino students as they are for White students. While numbers may be similar, they gloss over the individual stories of each of the students tracked in this study. Each case represents a student that tried to pursue a higher education.

This presents a moral imperative to university administrators. PWIs ought to serve all students, providing each the full measure of their aid. Each student that fails to persist enjoys fewer career opportunities, diminished lifetime earning potential, and is possibly saddled with student debt for which there was no reward. That Black and Latino students do not enjoy equivalent boosts to persistence odds is an injustice. It is cause for concern and action.

This also presents an economic imperative to university administrators. Competition for recruitment in the higher education sphere is fierce. Each student provides an institution with a reliable source of income for four or more years. Retention efforts among enrolled students can secure that revenue stream. This study's findings show that PWIs have room for growth in boosting Black and Latino students' chances at persisting.

The findings of this study are significant for practitioners. Residence hall administrators rightly point to the role they play in helping students get acclimated to the institution, connected to support services, and involved in the campus community. These activities clearly build a sense of belonging, which fortifies a student against the challenges that the pursuit of a postsecondary degree entails. That all students, regardless of race, experience an increase in the odds ratio of persistence as a result of living in residence halls should come as no surprise; this 
has been found repeatedly throughout literature on this topic. This is an endorsement of the field of residence life. These findings, however, challenge both practitioners and PWIs in general to reexamine how they serve non-majority students. Practitioners want their residence halls to be places where all students are welcomed, but this is not yet achieved.

The results of this study challenge PWIs to take additional steps to more fully commit the benefits of residence halls to Black and Latino students. While they currently enjoy an increase in their odds ratio of persisting as a result of living in a residence hall, the magnitude of this increase is not as great as that of White students. This disparity can be overcome through targeted action. Individual institutions should assess their campus climate, consult with all demographic populations, and revise their methods to meet this challenge.

The modern PWI should proactively and explicitly welcome nonwhite students. Although an additional dissertation could be written solely on this topic, some discussion is due on what institutions can do to foster a sense of belonging. Clear statements of intent (often in the form of "diversity statements" or institutional values) should be made public. Not only should "diversity" or "inclusion" be made part of those, but the institution should also offer an interpretation of what it means and how they implement it. Before incidents of bias occur on campus or in the nation, institutional leaders should demonstrate their commitment to Black and Latino students. Leadership teams and faculty rosters that are visually representative of the diversity of campus also implicitly convey that the campus celebrates the success of all students. Residence hall teams should take intentional steps to build a sense of belonging for Black and Latino students in particular. Unambiguous statements of welcome and values should make clear that the residence hall environment is one that can feel safe and supportive. These 
foundational steps, along with other institution-specific actions, should be taken to promote belonging.

The findings of this study also answer the concerns that I have held since I began working in the field of residence life. I have long wondered if the communities built in PWI residence halls equally meet the needs of all students. This study suggests that they do not. This is a fear realized. The results give me cause to reexamine my years directly managing residence halls, and the ways in which I made them second homes for diverse student populations. I wonder if, for my part, I did all that I could to assist Black and Latino students. While I may never know the answer to that question, I am satisfied to have answered the original query. I am glad to see that residence halls provide positive outcomes to all groups. To an extent, the available literature has indicated this for many years with no dispute. These findings further reinforce the value of residence halls. They promote student persistence, furthering the educational pursuits of those that live in them. 


\section{REFERENCES}

ACUHO-I (2015). ACUHO-I 2015 operational survey. Columbus, OH: M. Adams, E. Sorensen, \& M. Zabriskie.

Anderson, M. L., Goodman, J., \& Schlossberg, N. K. (2012). Counseling adults in transition: Linking Schlossberg's theory with practice in a diverse world (4th ed.). New York, NY: Springer Publishing.

American College Personnel Association (1975). A student development model for student affairs in tomorrow's higher education. In E. J. Whitt (Ed.), College student affairs administration (pp. 9-16). Needham Heights, MA: Simon \& Schuster.

American Council on Education (1937). The student personnel point of view. In E. J. Whitt (Ed.), College student affairs administration (pp. 17-24). Needham Heights, MA: Simon $\&$ Schuster.

Araujo, P., \& Murray, J. (2010). Estimating the effects of dormitory living on student performance. Economics Bulletin, 30(1), 866-878.

Astin, A. W. (1973). Measurement and determinants of the outputs of higher education. In L. Solmon \& P. Taubman (Eds.), Does college matter? Some evidence on the impacts of higher education (pp. 107-128). New York, NY: Academic Press.

Astin, A. W. (1984). Student involvement: A developmental theory for higher education. Journal of College Student Personnel, 25, 297-308.

Astin, A. W. (1993). What matters in college?: Four critical years revisited. San Francisco, CA: Jossey-Bass. 
Astin, A. W., \& Oseguera, L. (2012). Pre-college and institutional influences on degree attainment. In A. Seidman (Ed.), College student retention: Formula for student success (pp. 119-146). Lanham, MD: Rowman \& Littlefield.

Benton, M.A. (2001). Today's college student: Challenges African American students face at predominantly White institutions. Colorado State University Journal of Student Affairs, 10(1), 21-28.

Blimling, G. S. (2015). Student learning in college residence halls: What works, what doesn't, and why. San Francisco, CA: Jossey-Bass.

Brooks, S. E. (2010). The connection between residence life and first-year student retention at the University of Pittsburgh. Journal of College and University Student Housing, 37(1), 12-23.

Brown, R. D. (1974). Student development and residence education: Should it be social engineering? In In D. A. DeCoster \& P. Mable (Eds.), Student development and education in college residence halls (pp. 41-54). Washington, DC: American College Personnel Association.

Brown, R. D., Winkworth, J., \& Braskamp, L. (1973). Student development in a coed residence hall: Promiscuity, prophylactic, or panacea? Journal of College Student Personnel, 14(2), 98-104.

Budny, D., Paul, C. A., \& Newborg, B. B. (2014). Involving parents at step one in the freshman engineering experience. International Journal of Engineering Pedagogy, 4(2), 10-17. 
Chickering, A. W. (1974a). Education and identity: Implications for residence hall living. In D. A. DeCoster \& P. Mable (Eds.), Student development and education in college residence halls (pp. 76-86). Washington, DC: American College Personnel Association.

Chickering, A. W. (1974b). Commuting versus resident students. San Francisco, CA: JosseyBass.

Chickering, A. W., \& Reisser, L. (1993). Education and identity (2nd ed.). San Francisco, CA: Jossey-Bass.

Council for the Advancement of Standards in Higher Education (2014). Housing and residential life programs. Fort Collins, CO: C. Henry, \& D. Boykin.

Cross, J. E., Zimmerman, D., \& O’Grady, M. A. (2009). Residence hall room type and alcohol use among college students living on campus. Environment and Behavior, 41, $583-603$.

Davenport, M. Y. (2010). Examining involvement as a critical factor: Perceptions from first generation and non-first generation college students (Doctoral dissertation). Retrieved from ERIC. (ED519099)

DeAngelo, L. (2014). Programs and practices that retain students from the first to second year: Results from a national study. New Directions for Institutional Research, 160, 53-75.

DeVaney, S. A. (2015). Understanding the millennial generation. Journal of Financial Service Professionals, 69(6), 11-14.

Dickerson, D. (2007). Risk management and the millennial generation. Campus Activities Programming, 39(6), A12-A16. 
Dimock, M. (2019). Defining generations: Where Millennials end and Generation Z begins. Pew Research Center. Retrieved from http://www.pewresearch.org/fact-tank/2019/01/17/ where-millennials-end-and-generation-z-begins/.

Dovidio, J. F., Kawakami, K., \& Gaertner, S. L. (2002). Implicit and explicit prejudice and interracial interactions. Journal of Personality and Social Psychology, 82(1), 62-68.

Dusselier, L., Dunn, B., Wang, Y., Shelley, M. C., \& Whalen, D. F. (2005). Personal, health, academic, and environmental predictors of stress for residence hall students. Journal of American college health, 54(1), 15-24.

Eisenberg, D., Golberstein, E., \& Whitlock, J. L. (2014). Peer effects on risky behaviors: New evidence from college roommate assignments. Journal of Health Economics, 33, 126-138.

Foubert, J. D., Tepper, R., \& Morrison, D. R. (1998). Predictors of student satisfaction in university residence halls. Journal of College and University Student Housing, 27(1), 41-46.

Greyerbiehl, L., \& Mitchell Jr., D. (2014). An intersectional social capital analysis of the influence of historically Black sororities on African American women's college experiences at a predominantly White institution. Journal of Diversity in Higher Education, 7(4), 282.

Hagedorn, L. S. (2012). How to define retention: A new look at an old problem. In A. Seidman (Ed.), College student retention: Formula for student success (pp. 81-100). Lanham, MD: Rowman \& Littlefield. 
Harford, T. C., Wechsler, H., \& Muthén, B. O. (2002). The impact of current residence and high school drinking on alcohol problems among college students. Journal of Studies on Alcohol, 63(3), 271-279.

Inman, P., \& Pascarella, E. (1998). The impact of college residence on the development of critical thinking skills in college freshmen. Journal of College Student Development, $39,557-568$.

Johnson, D. R., Soldner, M., Leonard, J. B., Alvarez, P., Inkelas, K. K., Rowan-Kenyon, H. T., \& Longerbeam, S. D. (2007). Examining sense of belonging among first-year undergraduates from different racial/ethnic groups. Journal of College Student Development, 48(5), 525-542.

Jones, S. R., \& Abes, E. S. (2013). Identity development of college students: Advancing frameworks for multiple dimensions of identity. San Francisco, CA: Jossey-Bass.

Kanoy, K., \& Bruhn, J. (1996). Effects of a first-year living and learning residence hall on retention and academic performance. Journal of The First-Year Experience \& Students in Transition, 8(1), 7-23.

Krafft, L. R. (2014). The impact of college students' perceptions of residence hall environment on retention risks, as moderated by attachment style (Doctoral dissertation). Retrieved from ProQuest. (3643411)

Kuh, G. D. (1994). Creating campus climates that foster learning. In C. C. Schroeder \& P. Mable (Eds.), Realizing the educational potential of residence halls (pp. 109-132). San Francisco, CA: Jossey-Bass.

Kuh, G. D., Kinzie, J., Schuh, J. H., \& Whitt, E. J. (2005). Student success in college: Creating conditions that matter. San Francisco, CA: Jossey-Bass. 
Levine, A. (1994). Guerrilla education in residence life. In C. C. Schroeder \& P. Mable (Eds.), Realizing the educational potential of residence halls (pp. 93-106). San Francisco, CA: Jossey-Bass.

Long, L. D. (2014). Does it matter where college students live? Differences in satisfaction and outcomes as a function of students' living arrangement and gender. Journal of College and University Student Housing, 40(2), 66-85.

López Turley, R. N., \& Wodtke, G. (2010). College residence and academic performance: Who benefits from living on campus? Urban Education 45 , 506-532.

doi: $10.1177 / 0042085910372351$

Maxcy, S. \& Maxcy, D. (1997). The end of collegiality and the future of higher education. In J. J. Van Patten (Ed.), Watersheds in higher education (pp. 37-54). Lewiston, NY: Edwin Mellen.

Mayhew, M. J., Rockenbach, A. N., Bowman, N. A., Seifert, T. A., Wolniak, G. C., Pascarella, E. T., \& Terenzini, P. Y. (2016). How college affects students: 21st century evidence that higher education works (Vol. 3). San Francisco, CA: Jossey-Bass.

McCluskey-Titus, P., \& Oliver, R. (2001). The relationship between community development and academic achievement of undergraduate students in residence halls. College Student Affairs Journal, 20(2), 12-21.

Mertler, C. A., \& Vannatta, R. A. (2013). Advanced and multivariate statistical methods (5th ed.). Glendale, CA: Pyrczak Publishing. 
Nagda, B. R., Gurin, P., \& Johnson, S. M. (2005). Living, doing and thinking diversity: How does pre-college diversity experience affect first-year students' engagement with college diversity? In R. S. Feldman (Ed.), Improving the first year of college (pp. 73-110). Mahwah, NJ: Lawrence Erlbaum Associates.

Nelson Laird, T. F., \& Cruce, T. M. (2009). Individual and environmental effects of part-time enrollment status on student-faculty interaction and self-reported gains. Journal of Higher Education, 80(3), 290-314.

Padgett, R. D., Johnson, M. P., \& Pascarella, E. T. (2012). First-generation undergraduate students and the impacts of the first year of college: Additional evidence. Journal of College Student Development, 53(2), 243-266.

Pascarella, E. T. (2005). Cognitive impacts of the first year of college. In R. S. Feldman (Ed.), Improving the first year of college (pp. 111-140). Mahwah, NJ: Lawrence Erlbaum Associates.

Pascarella, E. T., \& Terenzini, P. T. (2005). How college affects students: A third decade of research (Vol. 2). San Francisco, CA: Jossey-Bass.

Pascarella, E. T., Terenzini, P. T., \& Blimling, G. S. (1994). The impact of residential life on students. In C. C. Schroeder \& P. Mable (Eds.), Realizing the educational potential of residence halls (pp. 22-52). San Francisco, CA: Jossey-Bass.

Penney, J. F. (1969). Student personnel work: A profession stillborn. In E. J. Whitt (Ed.), College student affairs administration (pp. 90-93). Needham Heights, MA:

Simon \& Schuster. 
Peters, J., Wakabayashi, P., Weppler, G., D’Alessio, M., \& Mudge, R. (2018). More than a place to eat and sleep: The value of living and learning in residence. Journal of College and University Student Housing, 45(1), 44-56.

Pike, G. R. (2002). The differential effects of on- and off-campus living arrangements on students' openness to diversity. NASPA Journal, 39(4), 283-299.

Pike, G. R., Schroeder, C. C., \& Berry, T. R. (1997). Enhancing the educational impact of residence halls: The relationship between residential learning communities and first-year college experiences and persistence. Journal of College Student Development, 38, 237-249.

Pring, R. (2015). Philosophy of educational research (3rd ed.). New York, NY: Bloomsbury.

Ross, S. E., Niebling, B. C., \& Heckert, T. M. (1999). Sources of stress among college students. Social psychology, 61(5), 841-846.

Schroeder, C. C. \& Mable, P. (1994). Residence halls and the college experience: Past and present. In C. C. Schroeder \& P. Mable (Eds.), Realizing the educational potential of residence halls (pp. 3-21). San Francisco, CA: Jossey-Bass.

Schudde, L. (2011). The causal effect of campus residency on college student retention. Review of Higher Education, 34(4), 581-610.

Schudde, L. (2016). The interplay of family income, campus residency, and student retention: What practitioners should know about cultural mismatch. Journal of College and University Student Housing, 43(1), 10-27.

Shook, N. J., \& Clay, R. (2012). Interracial roommate relationships: A mechanism for promoting sense of belonging at university and academic performance. Journal of Experimental Social Psychology, 48(5), 1168-1172. 
Shook, N. J., \& Fazio, R. H. (2008). Roommate relationships: A comparison of interracial and same-race living situations. Group Processes \& Intergroup Relations, 11(4), 425-437.

Stern, L. A., Powers, J., Dhaene, K., Dix, A., \& Shegog, S. (2007). Liking, cooperation, and satisfaction between roommates. Journal of College and University Student Housing, 34(2), 53-60.

Stimpson, R. (1994). Creating a context for educational success. In C. C. Schroeder \& P. Mable (Eds.), Realizing the educational potential of residence halls (pp. 53-69). San Francisco, CA: Jossey-Bass.

Thelin, J. R. (2004). A history of American higher education. Baltimore, MD: Johns Hopkins University Press.

Tinto, V. (1975). Dropout from higher education: A theoretical synthesis of recent research. Review of Educational Research, 45, 89-125.

Tinto, V. (1993). Leaving college: Rethinking the causes and cures of student attrition (2nd ed.). Chicago, IL: University of Chicago Press.

Tinto, V. (2012). Completing college: Rethinking institutional action. Chicago, IL: University of Chicago Press.

United States Census Bureau (2015). 2015 American community survey 1-year estimates: Characteristics of the group quarters population by group quarters type (Publication No. S2601B). Washington, DC: Government Printing Office.

United States Census Bureau (2016). Quickfacts. Retrieved from https://www.census.gov/quickfacts/table/PST045216/00

Vinson, K. (2013). Hovering too close: The ramifications of helicopter parenting in higher education. Georgia State University Law Review, 29(2), 423-452. 
Wechsler, H., Dowdall, G. W., Davenport, A., \& Castillo, S. (1995). Correlates of college student binge drinking. American Journal of Public Health, 85(7), 921-926.

Willoughby, B. J., \& Carroll, J. S. (2009). The impact of living in co-ed resident halls on risk-taking among college students. Journal of American College Health, 58(3), 241246. 
APPENDIX A: BPS DATA FILE CODEBOOK 